\title{
Post-Depositional Alteration of Calcium Carbonate Phases in Archaeological Ceramics: Depletion and Redistribution Effects
}

\author{
William D. Gilstrap ${ }^{1, *}$, Jennifer L. Meanwell ${ }^{1}{ }^{\mathbb{D}}$, Elizabeth H. Paris ${ }^{2}{ }^{(}$, Roberto López Bravo ${ }^{3} \mathbb{C}$ and \\ Peter M. Day ${ }^{4,5}$ \\ 1 Center for Materials Research in Archaeology and Ethnology, Massachusetts Institute of Technology, \\ Cambridge, MA 02139, USA; jmeanwel@mit.edu \\ 2 Department of Anthropology and Archaeology, University of Calgary, Calgary, AB T2N 1N4, Canada; \\ elizabeth.paris@ucalgary.ca \\ 3 Escuela de Arqueología, Universidad de Ciencias y Artes de Chiapas, Tuxtla Gutiérrez 29039, Mexico; \\ roberto.lopez@unicach.mx \\ 4 Institute for Nanoscience and Nanotechnology, N.C.S.R Demokritos, Agia Paraskevi, 15341 Athens, Greece; \\ p.m.day@sheffield.ac.uk \\ 5 Department of Archaeology, University of Sheffield, Sheffield S1 3NJ, UK \\ * Correspondence: gilstrap@mit.edu
}

Citation: Gilstrap, W.D.; Meanwell, J.L.; Paris, E.H.; López Bravo, R.; Day, P.M. Post-Depositional Alteration of Calcium Carbonate Phases in Archaeological Ceramics: Depletion and Redistribution Effects. Minerals 2021, 11, 749. https://doi.org/ $10.3390 / \min 11070749$

Academic Editor: Mark Golitko

Received: 18 May 2021

Accepted: 6 July 2021

Published: 9 July 2021

Publisher's Note: MDPI stays neutral with regard to jurisdictional claims in published maps and institutional affiliations.

Copyright: (c) 2021 by the authors. Licensee MDPI, Basel, Switzerland. This article is an open access article distributed under the terms and conditions of the Creative Commons Attribution (CC BY) license (https:// creativecommons.org/licenses/by/ $4.0 /)$.

\begin{abstract}
The final stage in the life history of prehistoric pottery prior to archaeological recovery is usually the longest, and frequently the most dynamic. The remains of archaeological ceramics spend hundreds to thousands of years deposited within the upper layers of the earth's crust where they encounter the same diagenetic environmental processes as the surrounding natural materials. Harsh conditions of subterranean environments induce physical stresses and chemical reactions, causing alterations of ceramic structure and composition. This is especially true of carbonate-rich ceramics, as carbonate phases are soluble when deposited within acidic environments. This paper examines common carbonate depletion and accretion effects of post-depositional environments on ancient ceramics from two rather different geological and archaeological contexts: Mesoamerica and the Mediterranean. Potters in both regions produce vessels with carbonate-rich materials—clays, calcite, limestone - that alter due to long exposure to low-pH sediments and continual water table fluctuations. Ceramic petrography is employed to identify traces of carbonate alterations within ceramic microstructure and to characterize fabrics. Elemental compositions of the same sherds are characterized through either scanning electron microscopy coupled with energy-dispersive spectrometry (SEM-EDS), inductively coupled plasma mass spectrometry and optical emission spectrometry (ICP-MS/OES) or neutron activation analysis (NAA). This method enabled comparison of the differing effects of post-depositional alteration of carbonate phases on bulk composition signatures commonly used to determine provenance.
\end{abstract}

Keywords: archaeological ceramics; sourcing; alteration; calcite; petrography; chemical composition

\section{Introduction}

Be they pot, brick or mortar, ceramic materials have been commonplace in human societies for millennia. These materials were a key, if often mundane, part of everyday life. Due to their resilience against natural decomposition, ceramics are found in abundance during archaeological excavations. They have become pivotal in our attempts to understand behavior and societal life in the human past to such an extent that entire conferences and academic societies are dedicated to ancient ceramics. Neff [1] (p. 1) suggests that a reason archaeologists became so seemingly "inordinately concerned with ceramics" is mainly one of pragmatism. Clearly, beyond the ubiquity of archaeological ceramics, the use of geological and organic raw materials in their production leaves traces of human behavior-including interactions with environments, economics, knowledge transfer, skill, and links to cognitive processes such as aesthetic choices and ritual behaviors. 
With the use of many instrument-based analytical techniques, archaeologists have been able to add a greater degree of precision and accuracy to their physical and chemical assessments of ceramic materials, thus opening up additional avenues for research into the human past. Studies of material provenance and reconstructions of past technologies are two mechanisms that archaeologists use to glean cultural and behavioral information from ceramic materials. Both attempt to answer several basic archaeological questions: What is it? When was it made and/or used? Where was it made and by whom? Technological inquiries go the extra step by attempting to determine how it was made, what were the steps used in production, how production processes affect material properties and whether any of these aspects change over time.

In essence, investigations of ancient materials, specifically ceramics, have expanded their interests from superficial classifications [2-6] and temporal modeling [7-10] towards behavior models of human-environment interaction and exchange [11-19] as well as reconstructions of materials engineering in the past [20-39]. If archaeologists have learned anything over the past century or so of ceramic studies, it is that archaeological ceramic materials are complex, composite materials often with long life histories, and they must be treated as such in order to ascertain meaningful and culturally valuable information.

Typically, only small portions of archaeological ceramic materials are available for the kinds of destructive analyses used to determine chemical and mineralogical composition, either due to their rarity or institutional and governmental regulations. Therefore, it is paramount that we understand exactly what is being analyzed. Scholars, such as Rice [40] (p. 347), have urged that care must be taken in developing interpretations of ceramic material properties, including chemical and mineralogical composition, as the material being studied is the product of indeterminate years of use and reuse as well as the natural and cultural phenomena that occurred during the hundreds to thousands of years since initial deposition. She cautions that analysts must be aware that "the physical, mechanical, and thermal properties of an excavated [ceramic] may be different from those of the newly fired [product]." It was using this lens that a number of researchers over the past few decades have systematically demonstrated the potential for and actuality of chemical and mineral changes during the period between artifact deposition and recovery events [20,41-49].

In an attempt to define the composition measured in ceramic bulk analyses, Neff et al. [49] (p. 202) and subsequently Golitko et al. [43] (p. 81) posit that five general hypotheses need to be considered as potential explanations of observed composition. We present an amended version of these hypotheses below:

Observed archaeological ceramic composition:

1. reflects the composition of the original raw materials and is controlled by local geology;

2. results from paste preparation techniques that have modified the original raw composition of each raw material component through the act of combining one or more clay-bearing materials with plastic or aplastic media;

3. has been modified by use of the ceramic (e.g., cooking, lime mortar mixing, etc.);

4. has been altered as a result of the burial environment;

5. reflects the combination of some or all of these five factors.

In other words, ceramics are the product of cultural processes involving the manipulation and thermal alteration of geological (and sometimes organic) materials. However, archaeological ceramics add two additional components - use and post-burial environmentboth of which present unknown sources for added chemical and mineralogical variation. This means that bulk analytical characterizations of archaeological ceramics are the product not only of a combination of the geological materials and cultural input that interest us primarily, but also incurred taphonomic processes [43] (p. 81). It is the latter which in some circumstances need to be considered in order for us to achieve our aims of meaningfully investigating provenance and technology.

This paper investigates the post-depositional or post-burial effects of natural environments on carbonates, specifically calcium carbonate (calcite) and calcite-dominated 
raw materials, such as limestone, marl, or calcareous clays, which are frequently used in archaeological ceramics. Using a combination of bulk elemental techniques, targeted chemical microanalysis and ceramic petrography we explore how to identify and account for two taphonomic processes that can affect interpretations of archaeological ceramic compositional data: carbonate depletion and accretion. We have selected two assemblages of archaeological ceramics from very different geographic, geological and climate zones: highland Chiapas, Mexico and coastal southern Greece, as each have clear evidence for post-depositional alteration as identified through ceramic petrography and both have elemental compositional data to compare. The overarching aim of this paper is to systematically identify the potential for taphonomic changes in ceramic composition due to carbonate phase alterations and illustrate the analytical methods available to identify and account for carbonate depletions and accretions in archaeological ceramic materials.

\subsection{The Structure of a Ceramic and Locations of Potential Post-Depositional Contamination}

To understand the potential for post-depositional alterations of a ceramic, the structure of the material must be considered. We follow a modified descriptive system derived specifically for fired clay structures as viewed through a petrographic microscope [50,51] (pp. 364-396). This model demonstrates the complexity and composite nature of ceramic materials by emphasizing the heterogeneity and structure of the object (Figure 1). We consider a ceramic to be composed of three discrete levels of structure:

1. Microstructure - the abundance, distribution, shape, size, orientation, and alteration of pores, textures within the micromass (materials $<0.01 \mathrm{~mm}$ in size), and texture and orientation of individual non-plastic grains [50] (p. 129);

2. Groundmass or Paste Matrix - the lithology of mineral and rock grains, or inclusions (>0.01 $\mathrm{mm}$ in size) and the micromass [50] (p. 129) [52];

3. Surface treatment-any modification to the ceramic surface, including smoothing, burnishing, slip, paint, glaze, incision, stamping, scraping, or any combination thereof.

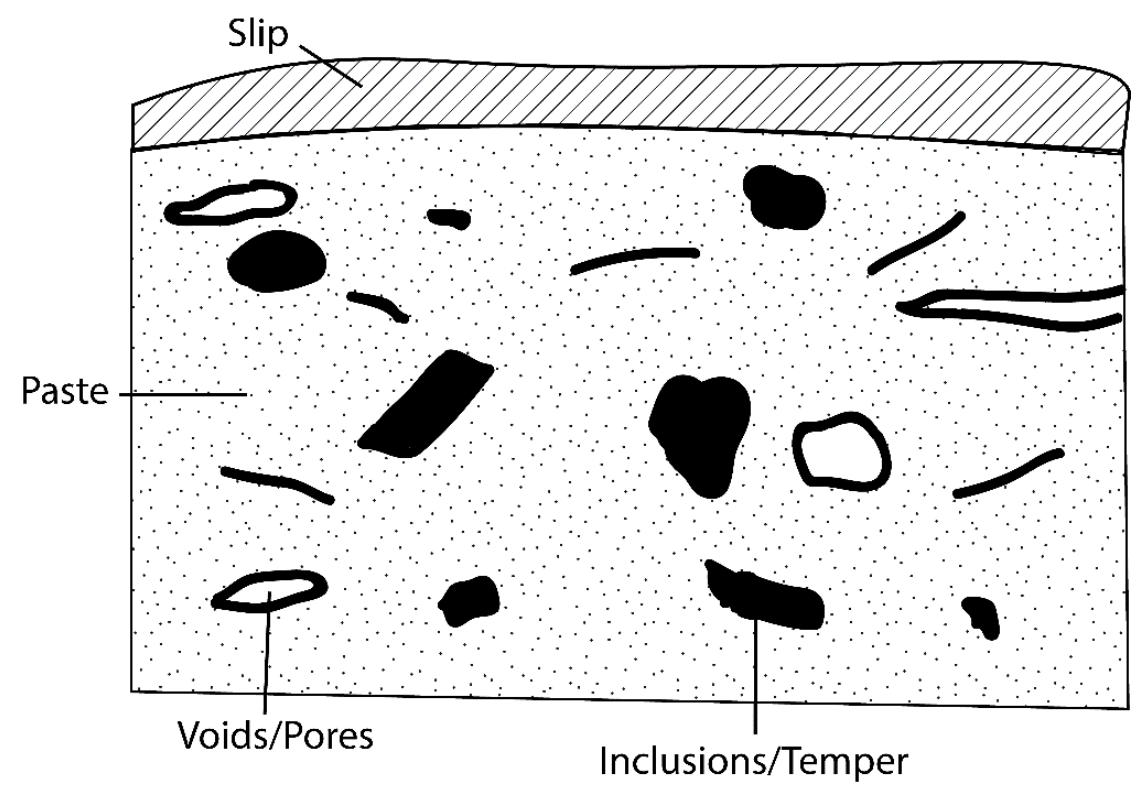

Figure 1. Diagram of a typical cross section of a ceramic object, including a slip, the paste, voids and inclusions. After [45] (p. 122, Figure 2).

In this model, individual grains are analyzed both in terms of their mineral and lithic composition as well as their shape, size, and orientation with respect to other grains and the ceramic surface. It considers individual grains in relation to their role as part of the micromass and as non-plastic inclusions suspended within the matrix. Grain size, shape, and distributions are also useful indicators of behaviors and choices made during 
production (i.e., tempering or forming techniques). The model also accounts for bulk and surface features, both those imposed as modifications during production and natural contaminants accumulated during the burial period of the ceramic life history. This stands in contrast to typical analytical methods, where contaminants are frequently assumed to affect only the surface layer of materials.

We pay considerable attention to the microstructural component of the ceramic system: pores and micromass. Pores, also referred to as voids, are homogeneous, bounded, discrete from other phases and are a major feature in virtually all ceramic materials [40] (p. 350). Essentially, pores are pockets of empty space bounded by the micromass alone or between individual grains and the micromass (Figure 2). Porosity is a significant factor in the performance characteristics of any ceramic material, specifically mechanical $[25,26,31,53]$ and thermal properties [54-56] and provides clues for determining forming technologies used in production [57] and function [58-60].

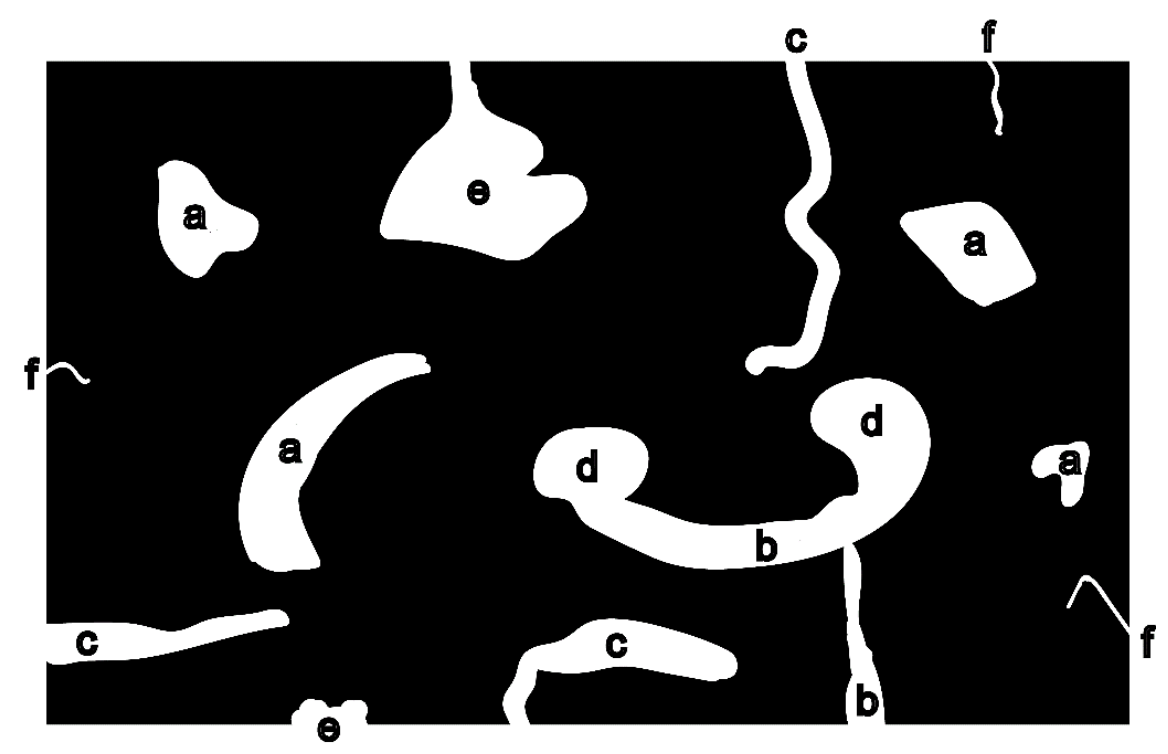

Figure 2. A schematic of various shapes and types of pores frequently identified in ceramics, including (a) closed pores (b) channel pores (c) blind-alley pores (d) loop pores (e) pocket pores (f) micropores. After [40] (p. 350, Figure 12.3).

Pores are particularly complex because they can be introduced and altered during various stages of production. Most pores become morphologically frozen within the micromass during the drying and firing stages of manufacture. This is due to a variety of changes, including clay shrinkage during drying and dehydration, and the effects of sintering and vitrification of the aluminosilicate (clay) materials within the micromass. Sintering refers to the physical process of transforming a powder into a solid body using heat [61] (p. 427) and is often misconstrued in archaeological science as "vitrification" [34]. True vitrification creates a liquid phase and a disordered, glassy structure. Sintering, by contrast, is a solid state diffusion process that can happen at lower temperatures than vitrification and which typically forms crystalline structures in the finished product. The sintering process is affected by a number of factors including the chemical composition of the micromass, vapor pressure and particle radius, but the most important are the temperature and soaking time [62] (p. 473). The solidification of the raw materials into a ceramic body is highly significant when considering the potential for phase alteration post-burial. It determines the porosity of a ceramic through freezing in place pores derived through forming or shaping mechanisms, unless they are filled in by extensive sintering or vitrification. Pores may also remain as empty spaces, as combustible organic material burns off during firing, or may occur due to bubble formation during the off-gassing of $\mathrm{CO}_{2}$ from carbonate materials undergoing heat-induced chemical changes such as 
calcination [40] (p. 350). The result of the firing process is a porous material susceptible to naturally occurring events similar to subterranean rock and mineral weathering, specifically chemical dissolution and recrystallization of minerals contained in groundwater solutions.

\subsection{Mobility of Calcareous Material in Archaeological Ceramics}

Calcareous clays and clay-rich marls are often used as raw materials for ceramic production in antiquity and these are highly susceptible to post-burial alterations in the form of calcium leaching or calcite dissolution and recrystallization throughout the ceramic microstructure [45]. Calcium leaching can occur as calcareous matter from the burial environment is dissolved by groundwater that has mixed with acid compounds derived from decay of organic matter. The $\mathrm{pH}$ of the groundwater can be low enough to dissolve carbonates and transport them as an aqueous solution that can travel through porous media [63]. Complete dissolution would mean that all carbonates within the ceramic system are transformed from a solid into ions in solution, which then may be transported out of the system and into the burial environment. As the groundwater dries, it may redeposit alkaline matter within the microstructure of a buried ceramic. This phenomenon is termed complete allochthonous (CA) secondary calcite deposition [42] (p. 9). Groundwater with a low $\mathrm{pH}$ can also create a similar effect upon the micromass of a calcareous ceramic by dissolving and redistributing crystalline carbonate matter within the confines of the ceramic microstructure itself. This phenomenon is termed partial allochthonous (PA) secondary calcite deposition [42] (p. 9).

Cau Ontiveros et al. [42] describe a broad spectrum of post-burial alterations and contamination of ceramic systems and modes of identification available to archaeologists and so we will not discuss these in great detail here. However, it is worth mentioning the main types of secondary calcite deposits, or accretions, they noted:

1. Void infilling - crystalline matter located within pores and cracks that is birefringent under a petrographic microscope [42] (p. 17, Figure 1g); see also [64-71] (p. 59).

2. Microgeodetic crystallization on walls of pores and cracks-crystalline calcite projecting from pore and crack surfaces similar to mineral formations viewed in geodes [42] (p. 17, Figure 1c,e,f); see also [72-75].

3. Patches of cryptocrystalline calcite (micrite)—nodules or patches of cryptocrystalline calcite distributed throughout the groundmass [42] (p. 17, Figure 1a,b); see also [71] (p. 55, Plate 9e,f), [75-77].

4. Superficial deposits of calcium carbonate-carbonate layers coating the exterior surface of a ceramic. Cau Ontiveros et al. note that the accretion of carbonate matter on the ceramic surface may have little to no relationship with the presence of secondary calcite within the ceramic matrix [42] (p. 17, Figure 1h).

5. Textural deformation of the microstructure-birefringent crystallites within the micromass. Often these are observed as striations or patches within the micromass and can often obscure features within both the microstructure and groundmass [42] (p. 17, Figure 1d).

Calcite alteration and redistribution is a regularly occurring process in geological environments and the kinetics of the dissolution of calcite and calcium carbonate-bearing rocks and sediments is of great interest to geologists [78-81]. Published data suggest that the calcite dissolution rate increases steeply from $\mathrm{pH} 4$ to 1 , but the rate is reasonably flat across the middle of the $\mathrm{pH}$ scale before falling off slightly again at high $\mathrm{pH}$. Grain morphology also has a large effect on the system, due to changes in surface area and the formation of surface pitting and steps, which can affect the rate of dissolution by a factor of up to 100 [78]. Temperature can also affect the solubility of carbonate ions in groundwater, although if samples are deeply buried (as in many archaeological contexts), the temperature is unlikely to change dramatically from day to day. Therefore, it is not a simple calculation to determine how fast calcite can be dissolved out of a ceramic buried in acidic soils or, in fact, whether the carbonates will be attacked. 
Both crystalline calcite and calcium carbonate-bearing rocks are commonly used in the production of archaeological ceramics, but are also used in lime-based mortars. Although studies on mortars are less common than those on ceramics, several researchers have investigated the mobility of calcium ions and carbonate ions within a lime-based mortar [82-84]. As in traditional clay-based ceramic materials, calcium mobility in mortars requires additional research.

Archaeologists attempt to mitigate post-depositional effects by the mechanical removal of the ceramic surface exposed to the burial environment $[85,86]$, leaving only the microstructure and groundmass in the final measured elemental signature. Unfortunately, both the groundmass and the microstructure are also prone to chemical and physical alterations that may be unidentifiable without the use of ceramic petrography or chemical microanalysis (elemental mapping) of the microstructure.

\subsection{Post-Depositional Alteration of Calcite and Archaeological Interpretations of Compositional Data}

If our analyses of ancient ceramics are to produce meaningful data to improve our knowledge and interpretations of past behavior and culture groups, we must fully acknowledge their material and biographical complexity. Ceramic materials-earthen pottery, refractories, cementitious mortars and concrete, porcelain, etc.-are composed of heat-treated clay-rich sediment, a porous medium often containing a large proportion of non-plastic agents. They were used by people for unknown lengths of time and for a myriad of purposes, many unknown or unidentifiable to us. After use, they spend the majority of their existence buried underground and undergo the same processes of weathering and decay as all other inorganic matter within their burial environment. Such a lengthy and complicated presence in the world means that in order to gain data reflective of human behavior and culture, ceramics require us to gather many types of information through a variety of analyses [87]. We must accept that the data we generate through any one technique contains chemical and physical residues aggregated over the span of its existence. We do this with the explicit conclusion that data derived from ancient ceramic materials are "properties that exist after years of use and post-depositional alteration; they are 'remnant,' 'residual,' or apparent properties that can be used to estimate the ancient parameters but are not necessarily equivalent to them" [40] (p. 347-348; emphasis added).

Archaeologists have tried a variety of means to mitigate the potential for postdepositional alterations affecting the results of chemical composition studies. Statistical analyses of chemical data are regularly carried out using base-10 logarithms of elemental concentrations. Use of log concentrations rather than raw data compensates for differences in magnitude between the major elements, such as $\mathrm{Na}$, and trace elements, such as the rare earth or lanthanide elements (REEs). Transformation to base-10 logarithms also yields a more normal distribution for many trace elements. Though the utility of log transformations is debatable, this step puts data of all factors (i.e., per cent, ppm, ppb) on a level playing field expressed as a logratio [20,88].

Buxeda i Garrigós [20,89] further argues that variability added to a chemical compositional dataset is readily identified through the use of a total variation matrix (TVM) originally developed by Aitchison [88]. This method produces a series of variation matrices in which the sum of the variances in each column of the matrix is examined and contributes to the total variation of the element in question, which is then used as a devisor against all other elements [86]. A high ratio indicates low variability. TVM is a relatively quick technique for exploring elemental datasets and identifying analytes that present the highest and lowest variability. The element with the lowest variability can be used as the divisor to transform the entire dataset into logratios, which should help diminish any effects of variability added through post-depositional processes including elemental leaching [41,90].

Mommsen and Sjöberg [91] (pp. 361-362) argue that, since post-burial alterations may occur as accretions of matter from the environment, they may also be treated as dilutions. They state that relying "strongly" on a single element for a denominator, as with logratio transformations, is a drawback and that shifts in concentration data due to alteration or 
contamination should be corrected using a dilution factor. This dilution factor or "best relative fit factor" is applied to each sample within a group made of similar raw materials to fit each sample to the average concentration values of the group. This procedure should create a "better defined 'sharper' pattern" for the group, thereby shrinking the statistical spread of elemental concentration values [91] (p. 362) and reducing effects of any variability added due to post-burial alteration.

In this paper, we examine the post-depositional alterations of minerals, specifically carbonates, within ceramic material systems that are prevalent in the archaeological record and investigate how they may affect the outcome of bulk compositional analyses, chemical or physical. We argue that, in certain cases, significant accretion or depletion of mineral components used in the production of archaeological ceramic objects may lead to misinterpretations of compositional and microstructural data, even with mitigating factors in place. Such issues are problematic in developing archaeological interpretations of bulk elemental data, including construction of the reference groupings many archaeologists depend on for provenance determination and raw material characterization. Key microstructural information, including porosity, optical activity of the micromass [50] and mineralogical composition of the groundmass may be obfuscated, thus clouding investigations of technology. While some researchers have determined that some post-depositional alterations had no effect on their compositional assessment [43], others have demonstrated clear evidence to the contrary $[20,41,48,90]$. Provided that there is at least some potential impact on the accuracy of archaeological interpretations of ceramic data, post-depositional alterations of compositional components must be investigated and either accounted for or ruled out completely. The destructive nature of most analytical techniques compounded by misleading data can obscure our understanding of past peoples and their actions.

\section{Materials and Methods}

Two ceramic assemblages were selected for analysis, one from Early Postclassic period Chiapas, Mexico and another from the Late Bronze Age Saronic Gulf, Greece. Each assemblage consists of ceramic materials, mainly pottery, manufactured with a significant input of some form of calcium carbonate. These particular assemblages were chosen because they display evidence of post-burial alteration to carbonate matter in the form of calcite mineral depletion, accretion, or redistribution as either PA or CA calcite deposition. Each assemblage has been fully analyzed through ceramic petrography and elemental composition analysis by neutron activation analysis (NAA) or inductively coupled plasma mass spectrometry and optical emission spectrometry (ICP-MS/OES). When possible, a subset of samples was subjected to targeted microanalysis by energy dispersive spectrometry (EDS) in which we mapped the abundance of major elements within a cross-section of the ceramic system. The high resolution and magnification of a scanning electron microscope enable us to explore all crystalline carbonate matter within the groundmass and microstructure. In each case study, the results of both elemental and petrographic analyses are compared for consistency. We use a combination of optical observations of microstructures, mineralogy, and statistical procedures to investigate and resolve any compositional discrepancies.

\subsection{Case Study 1: Jovel Valley Archaeological Context and Geology}

The Jovel Valley is located in the Central Plateau of highland Chiapas, Mexico, where the modern city of San Cristobal de las Casas, founded in the Colonial period, occupies the valley floor. The terrain of the Central Plateau is steep and mountainous, with its highest peaks reaching altitudes of over 2800 masl; it is colloquially characterized as "tierra fria", with short agricultural growing seasons and traditionally low population densities compared to neighboring lowland polities [92]. Yet, the Jovel Valley shows evidence of human habitation from the Late Pleistocene-Early Holocene transition (12,000-9300 CalBP) onward [93-95] due to its rich mineral and forest resources. The Jovel Valley is the largest intermontane valley in highland Chiapas, and it was historically significant for its strategic position along long-distance trade and transportation routes across central Chiapas [96,97]. 
From the Classic period onward (ca. $500 \mathrm{CE}$ ), highland Chiapas was characterized by a network of small polities [97], many of which were continually occupied through the 9th century CE "Maya Collapse" that affected many of their lowland counterparts. The position of the Jovel Valley on the western frontier between Maya-speaking polities of the highlands and their Zoque and Chiapanec neighbors to the west is reflected in the variation of interregional influences visible in its diverse material culture assemblages [98-100], and even its local utilitarian pottery reflects highly variable vessel forms, styles, and production techniques [96].

The present study sample was excavated from domestic midden contexts as part of the Proyecto Económico de los Altos de Chiapas project, co-directed by Elizabeth Paris and Roberto López Bravo [96-100]. The project investigated two Late Classic to Early Postclassic (600-1250 CE) Maya polities, Moxviquil and CV-38. These two sites are located on opposite sides of the Jovel Valley (Figure 3), with Moxviquil being the largest and most heavily investigated [97-100].

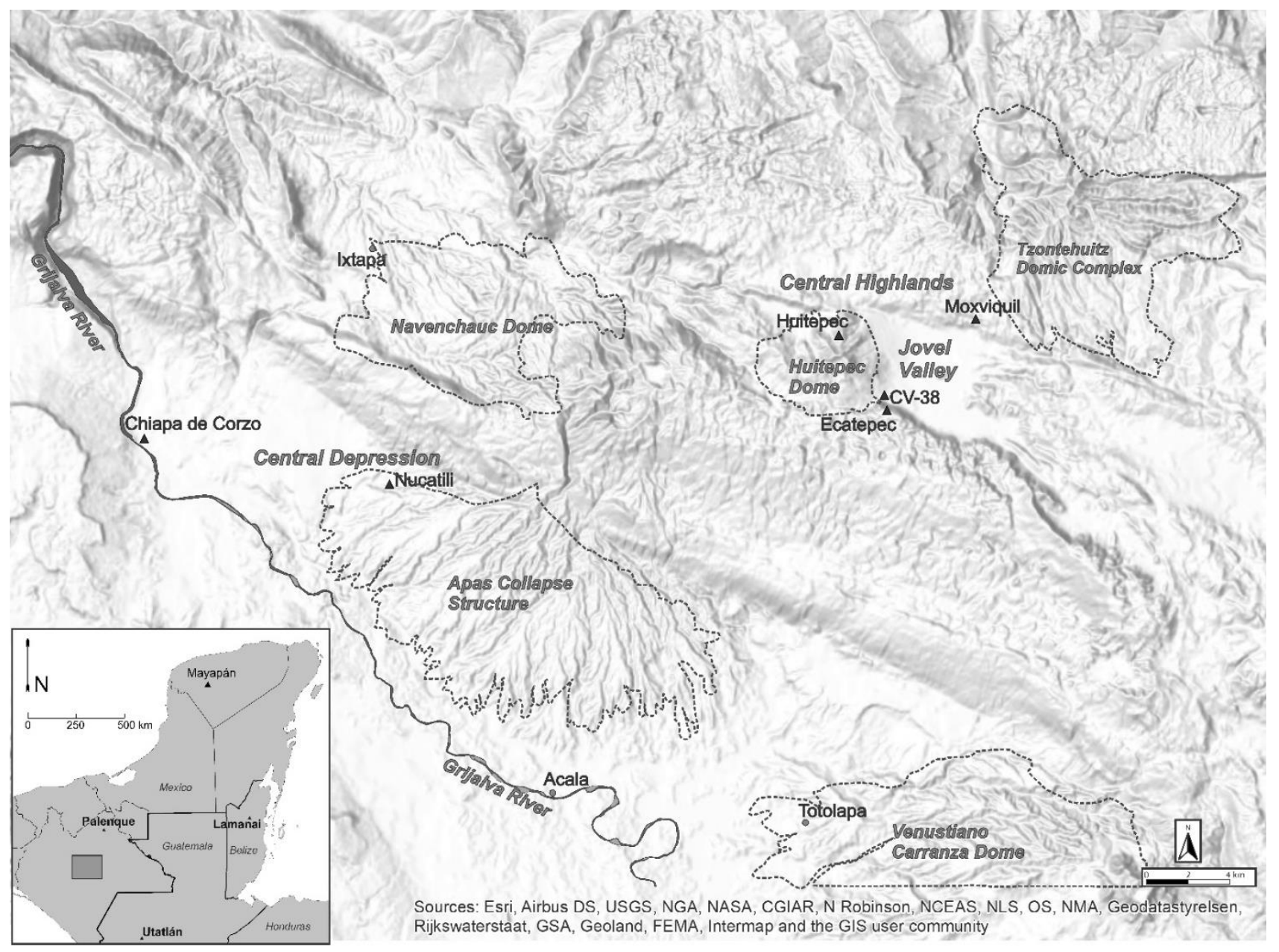

Figure 3. Map of Central Chiapas, including sites mentioned in the text, with volcanic domes and structures after [101] (Figure 4). Map by Tim Sullivan and Elizabeth Paris. 


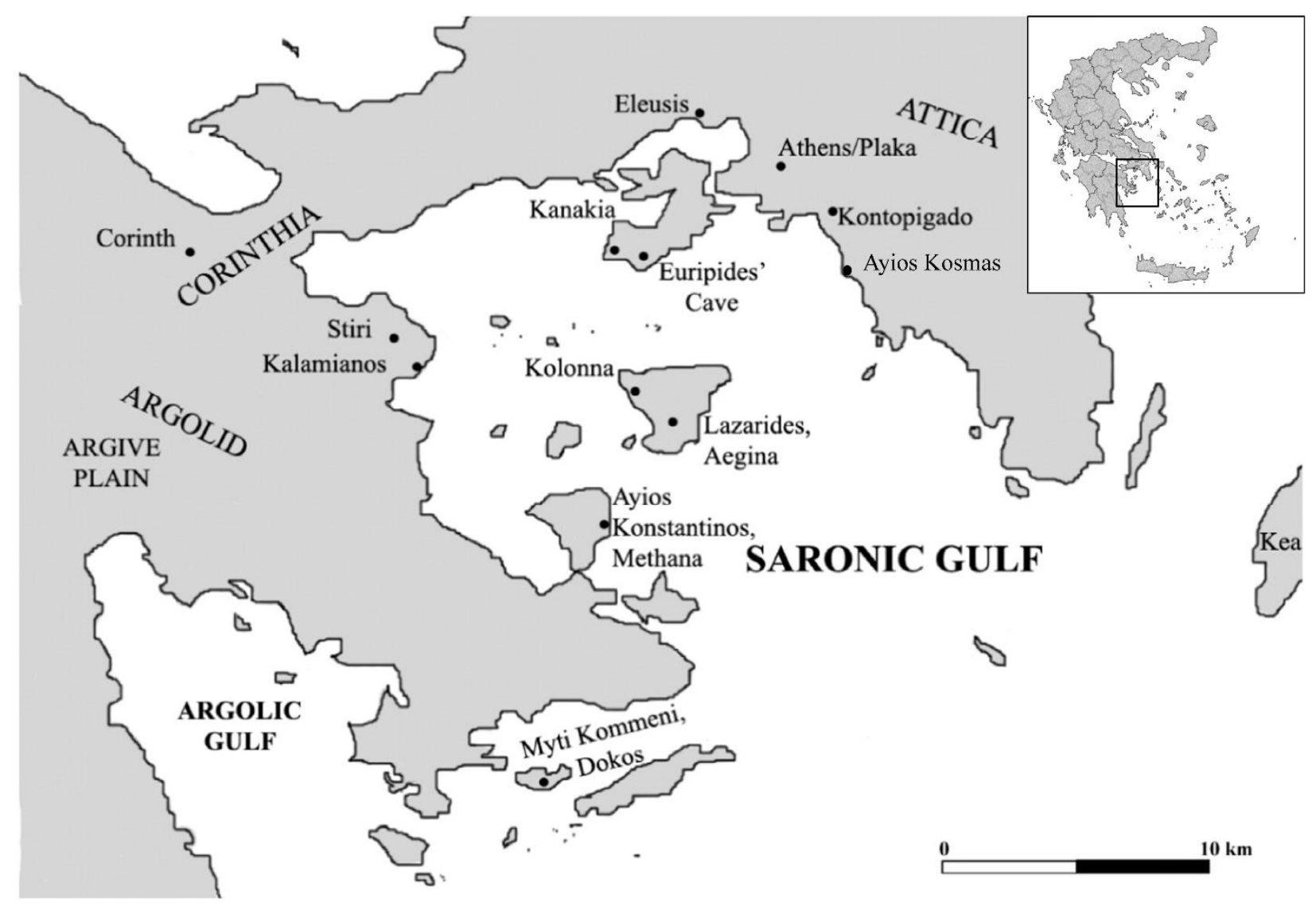

Figure 4. Map of the Saronic Gulf, Greece and all sites from within the study. Map by William Gilstrap.

The Jovel Valley is a geologically diverse area, with the valley floor being limestone surrounded by karstic hills and ridges [101]. The area is also within the Chiapas Volcanic Arc (CVA), with the dome of Huitepec located on the southwestern edge of the Jovel Valley and the large dome of Tzontehuitz located $18 \mathrm{~km}$ to the northeast of the valley (Figure 3). These geological resources provided Maya potters living in the valley with a wide variety of materials for their pottery, including volcanic ash, calcareous material, and larger mineral grains from the breakdown of volcanic rocks.

The Jovel Valley is home to a variety of conditions that can cause significant postdepositional alteration of pottery. As with most of the west coast of Mexico, the valley has a pronounced wet-dry seasonal shift, with a rainy season typically from May through October, leading to yearly cycles in soil humidity. The valley floor is also prone to flooding, which may be a partial reason why many of the Maya sites in the region are located on ridges or high points around the edge of the valley, rather than the valley floor. Studies of the soils from highland Chiapas note high acidity (between 4.7-6.6), with a low concentration of basic ions [102]. The uncultivated lands in the area are typically Pine-Oak Forest with some microclimates of Evergreen Cloud Forest [102-104]. Paris and López Bravo noted during excavation that bone preservation was decent, although subsequent C14 analysis revealed significant collagen degradation in some specimens; additionally, the degradation of calcareous material was visible in many ceramic sherds during excavations and laboratory analysis.

\section{Case Study 1: Jovel Valley Methods}

Thin section petrography was conducted on a total of 115 exported sherds from Moxviquil and CV-38. These sherds were exported in two groups to investigate the variability in pottery production within and across ten pottery types, including eight types interpreted as local to the Jovel Valley [92,97]. Thin section petrography methods 
used a modified version of Whitbread's descriptive system [105,106]. In this, detailed observations of the microstructure, groundmass, and inclusions are made and the samples are grouped into fabrics, which are collections of sherds that exhibit the same raw materials and processing techniques. The first 55 samples were given sample numbers MOX-1 through MOX-55, while the second collection of 60 were given numbers M1-M60. Only the second collection was available for chemical analysis.

The Jovel Valley collection includes a fabric that is tempered with calcareous material, a ceramic type called San Gregorio Coarse, originally identified by T. Patrick Culbert [92]. San Gregorio Coarse is an Early Postclassic diagnostic type that is widely distributed throughout highland Chiapas, and it is still unclear whether the vessels are made in multiple locations or whether some of them were traded around highland Chiapas [106].

Meanwell's [105,106] petrographic analysis of the San Gregorio Coarse identified calcareous material in various stages of preservation within the matrix, likely due to small, localized variations in burial conditions. Within one petrographic fabric, we have examples where the calcite inclusions are intact and visible throughout the sample, examples where they are only preserved in the center of the sherd, and examples where they have been completely weathered away, leaving mineral-shaped voids. This collection, then, represented an excellent case study where the effects of calcite dissolution could be studied.

A total of 19 of 115 sherds from the exported sample belonged to the San Gregorio Coarse type; of these, 14 were available for chemical analysis in the present study. Additionally, one sherd from an unidentified type was sorted into the calcareous fabrics and was included in this study. Nine sherds were classified as C-1 fabric and are discussed in this paper (see Table 1). Sherds were sampled for ICP-MS/OES (Perkin Elmer 9000 ICP-MS; Agilent 7700 ICP-OES) measurement at ActLabs, Ancaster, Ontario, Canada. Each sherd had the surface layers removed and was then crushed in an agate mortar before shipment. Upon arrival, the samples were processed using the RX4 mild steel milling procedure and homogenized to make sure all of the material would pass a 200 mesh. The samples were then subjected to a sodium peroxide total fusion digestion procedure and analyzed with the Ultratrace 7 package via ICP-MS/OES. The digestion method incorporates a caustic acid mixture suitable for digesting all silicate matter and a subsequent sodium peroxide fusion digestion that attacks many of the typically resistant minerals including quartz and other network silicates, zircons, and iron oxides. This method is similar to that devised by Kennett et al. [107] (p. 444-446). The dissolved ceramic solution is introduced into the ICP system that utilizes a combination of OES and MS elemental quantification techniques resulting in 55 element analytes for each ceramic specimen.

As it is impossible to visually distinguish among calcareous minerals such as calcite, dolomite, and aragonite by using purely visual petrography (without chemical staining techniques), two sherds from fabric C-1 were investigated using SEM-EDS to determine the chemical composition of the carbonate grains. Microanalysis of carbonates were conducted using a TESCAN Vega3 SEM with an attached Bruker Quantax EDS (Masic Lab; MIT, Cambridge, MA, USA). Samples were impregnated with an epoxy resin and polished to $1 \mu \mathrm{m}$ and subsequently analyzed uncoated and under low vacuum (15 Pa) with the electron beam set a $20 \mathrm{keV}$. Once carbonate grains were identified, EDS chemical maps were generated to resolve the spatial distribution of major elements, including $\mathrm{C}, \mathrm{O}, \mathrm{Na}, \mathrm{Mg}$, $\mathrm{Al}, \mathrm{Ca}, \mathrm{Fe}$ and $\mathrm{Ti}$, for $300 \mathrm{~s}$. Upon the completion of the chemical maps, spot analyses were measured at the scale of 1 px within the carbonate grains at random. In this way, we were able to determine whether the carbonate grains were calcite, dolomite or magnesian calcite. 
Table 1. List of the sherds presented in the paper with notes on whether they were sampled for chemical analysis. N- “No, analysis not carried out"; Y_-“Yes, analysis conducted".

\begin{tabular}{|c|c|c|c|c|c|}
\hline Sample & Ware & Site & Fabric & ICP-MS/OES & SEM-EDS \\
\hline MOX-31 & San Gregorio Coarse & Moxviquil & $\mathrm{C}-1$ & $\mathrm{~N}$ & $\mathrm{~N}$ \\
\hline MOX-32 & San Gregorio Coarse & Moxviquil & $\mathrm{C}-1$ & $\mathrm{~N}$ & $\mathrm{~N}$ \\
\hline MOX-33 & San Gregorio Coarse & Moxviquil & $\mathrm{C}-1$ & $\mathrm{~N}$ & $\mathrm{~N}$ \\
\hline MOX-34 & San Gregorio Coarse & Moxviquil & C-1 & $\mathrm{N}$ & $\mathrm{N}$ \\
\hline MOX-35 & San Gregorio Coarse & Moxviquil & $C-1$ & $\mathrm{~N}$ & $\mathrm{~N}$ \\
\hline M46 & San Gregorio Coarse & Moxviquil & C-1 & $\mathrm{Y}$ & $\mathrm{Y}$ \\
\hline M47 & San Gregorio Coarse & Moxviquil & C-1 & Y & $\mathrm{N}$ \\
\hline M48 & San Gregorio Coarse & Moxviquil & OTHER & Y & $\mathrm{N}$ \\
\hline M49 & San Gregorio Coarse & Moxviquil & C-1var & Y & $\mathrm{N}$ \\
\hline M50 & $\begin{array}{c}\text { Unidentified: Fine Paste } \\
\text { Red Ware }\end{array}$ & Moxviquil & C-1 & $Y$ & $\mathrm{~N}$ \\
\hline M51 & San Gregorio Coarse & Moxviquil & $\mathrm{C}-2$ & $\mathrm{Y}$ & $\mathrm{N}$ \\
\hline M52 & San Gregorio Coarse & Moxviquil & $\mathrm{C}-2$ & $\mathrm{Y}$ & $\mathrm{N}$ \\
\hline M53 & San Gregorio Coarse & Moxviquil & C-2var & $\mathrm{Y}$ & $\mathrm{N}$ \\
\hline M54 & San Gregorio Coarse & Moxviquil & $\mathrm{C}-2$ & Y & $\mathrm{N}$ \\
\hline M55 & San Gregorio Coarse & Moxviquil & $\mathrm{C}-2$ & $\mathrm{Y}$ & $\mathrm{N}$ \\
\hline M59 & San Gregorio Coarse & Moxviquil & $\mathrm{C}-1$ & Y & $\mathrm{Y}$ \\
\hline M31 & San Gregorio Coarse & CV-38 & C-1 & $\mathrm{Y}$ & $\mathrm{N}$ \\
\hline M36 & San Gregorio Coarse & CV-38 & $C-1$ & $\mathrm{Y}$ & $\mathrm{N}$ \\
\hline M40 & San Gregorio Coarse & CV-38 & C-1 & $\mathrm{Y}$ & $\mathrm{N}$ \\
\hline M41 & San Gregorio Coarse & CV-38 & C-1 & Y & $\mathrm{N}$ \\
\hline
\end{tabular}

\subsection{Case Study 2: Mycenaean Fineware Pottery Archaeological Context and Geology}

The Saronic Gulf is a body of water that has proved to have a major impact on social and cultural development throughout the course of human occupation of the Greek mainland. Its location between the Northeast Peloponnese and Attica enabled easy access to plentiful resources of food and raw materials to local coastal communities, as well as providing a major thoroughfare for both people and goods for millennia. The region is a unique network of intervisible islands and landforms, which promotes a sense of connectivity among its inhabitants [108] and likely led prehistoric populations to explore the islands and shores and exploit the many available natural resources.

Much of the land surrounding the gulf is composed of limestone, marl, sandstone and flysch with pockets of conglomerate, chert, as well as ophiolite outcrops in the north and west. Attica, however, is part of the Attic-Cycladic metamorphic belt (massif) and includes formations of schist, phyllite and marble [108]. The entire Saronic Gulf region additionally has large swaths of land covered by Neogene and Pleistocene marine sediments and alluvium. The island of Salamis is formed of largely similar geological components as the Attic mainland [109], while the island of Aegina, much like the Methana peninsula on the western coastline, is composed of a combination of andesite and dacite bearing pillow lavas, limestone and Neogene sediments [110] (pp. 71-92). Though only a snapshot in the long history of pottery production on all sides of the Gulf, ceramic production and distribution during the Mycenaean period provides a glimpse into the organization and development of craft in the context of early complex political economies.

Ceramic studies in the Aegean show ample evidence for the mixing of raw materials, specifically clay-rich sediments, rendering raw material provenance determination to any individual source difficult [111-115]. However, over 50 years of continuous systematic study of comparative materials enables us to compare unprovenanced ceramic materials with assemblages with known production origins, i.e., petrographic and chemical reference groups. As with many ceramic materials from the Bronze Age Aegean, both fabrics selected for this study were manufactured using calcareous clays whose calcareous component, however, is so finely dispersed that it is not always visible petrographically in fired ceramic matrices. The granularity of these fabrics varies considerably as does their estimated 
firing temperatures. Lastly, each fabric exhibits evidence of calcite alterations in the fabric microstructure and groundmass. Cau et al. [42] (p. 9) note the irony in that the calcareous nature of the raw materials used to produced ceramic materials in the Aegean is also that which causes so many problems for the ceramic analyst in the present day. The burial conditions are often alluvial sediments resultant of natural weathering of calcareous rocks and corrosive marine environments providing prime circumstances for carbonate alterations and contamination to take place. The porous structure of most ancient ceramics, combined with the burial conditions, mean that the accrual of secondary calcite alteration effects a problem for all ceramic materials, calcareous or not.

\section{Case Study 2: Mycenaean Fineware Pottery Methods}

This second case focuses on the effect of the alteration products on construction of elemental composition groups derived through bulk chemical analytical techniques, specifically NAA. The assemblage of ceramic materials in this case are from the first author's doctoral research project: "Ceramic Production and Exchange in the Late Mycenaean Saronic Gulf" [116]. The project examined over 350 ceramic fragments from 11 sites (Figure 4) using a suite of chemical and physical techniques including ceramic petrography, NAA and electron microscopy. The data were used to reconstruct aspects of production technology, social organization and political economy of Mycenaean regional groups at the end of the Late Bronze Age, roughly 1300-1130 BCE. Integration of the chemical and petrographic data revealed over 30 ceramic fabric groups, several of which enabled the identification of three dominant potting centers in the Saronic Gulf at this time and regionally specialized technological practices respective to vessel type and function [111].

This paper reflects on post-depositional calcite alteration products identified in two of the most common ceramic fabrics from the Saronic Gulf study, SAR-1 and SAR-11. SAR-1 contains 133 sherds from eight sites (See Supplementary Table S1) and SAR-11 comprises 69 sherds from eight sites (see Supplementary Table S2). Carbonate alterations are frequently observed in both fabrics as PA and CA, accounting for more than $30 \%$ of total group members in each fabric. The ceramic fabrics are described in detail using a modified version of Whitbread's method for describing ceramics in thin section [50]. The sherds that make up these fabric groups were analyzed by NAA at the University of Missouri Research Reactor (MURR), Columbia, MO, USA. Samples were prepared by removing the surface of the sherd using a tungsten carbide grinding bit with a Dremel rotary tool and subsequently pulverized using an agate mortar and pestle until powder could be pressed through a $1 \mathrm{~mm}$ screen. Powdered samples were weighed and placed into quartz vials and irradiated using the methods detailed by Glascock $[85,117]$. Statistical methods typical for ceramic sourcing [86] were employed to examine whether any elemental variability was introduced as a product of the calcite alteration process. Particular attention was paid to the samples where post-depositional alteration products are visible in thin section. Finally, we examined if any elemental variability introduced through post-burial processes affected the outcome of the cluster analysis and subsequent archaeological interpretations.

\section{Results and Discussion}

\subsection{Case Study 1: Jovel Valley Calcite Tempered Wares: Calcite Depletion Effects}

Broadly speaking, the pottery from Moxviquil and CV-38 separates into three inclusion categories: ash, calcite, and volcanic-derived mineral and rock fragments. These overarching fabric groups correspond quite well to the pottery typology for the Jovel Valley [92,97], with the fine serving wares typically made from ash-tempered fabrics, and the more utilitarian wares split between volcanic and calcareous fabrics.

As a general pattern, the pottery made and used in the Jovel Valley was fired at relatively low temperatures, with optically active clay matrices. Most of the vessels studied were fired in oxidizing atmospheres, with the exception of the Viejo Black wares, which appear to have been fired in a reducing atmosphere. All wares were tempered by the potters with a variety of different materials, although some fabrics exhibit more extensive 
processing than others. It is likely that many of these materials were found as sand deposits in nearby rivers and streams but, in many cases, the fragments are angular enough to suggest deliberate crushing before addition. Finally, all types studied here were made with non-calcareous clays. While San Gregorio Coarse vessels are unslipped and are typically undecorated, many other local serving and storage vessels were typically slipped [92,97]; however, because the soils were fairly acidic, many slips were highly eroded. Other ceramic types from elite contexts present decorative techniques such as incising, painting, filleting, molding and carving, modeling and carving, resist decoration, and stucco coatings [118].

In addition to eroding the slips from vessels, petrographic analysis suggests that the acidic soil conditions attack calcareous inclusions within the sherd walls during burial. This process leaves distinctive voids that have been described as ghost particle voids or calcite ghosts [66] (pp. 172-174); [119,120].

\subsubsection{Jovel Valley Calcareous Fabrics}

The predominant calcareous group, C-1, contains inclusions of calcite, often with well-developed twinning or pressure lamellae and intact cleavage planes (Figure 5). This fabric is found at both Moxviquil and CV-38. In some cases, the calcite has been weathered out by the acidic soil, and only voids remain. These voids are distinctively mineral-shaped, with many exhibiting straight-line edges that match the cleavage planes of calcite (Figure 6). These voids also sometimes have a very fine line of bright micrite visible along the interior of the boundary (Figure 7). Among this group, some of the sherds contain no calcite, some have partially intact calcite (particularly in the center of the sherd), and some contain intact calcite grains, likely due to small differences in the post-depositional environment (Figure 8 ). The calcite grains (and ghost particle voids) are typically medium sand sized, with some that are coarse sand and some fine sand, and often exhibit characteristic calcite cleavage planes. The calcite grains are typically the largest inclusions in the fabric, and tend to fall into a narrow size range, suggesting that they were deliberately added into the clay as a tempering material. However, as discussed above, some samples are tempered primarily with coarse and medium sand sized grains and others are tempered with medium to fine sand sized grains, leading to a slight visual texture difference.

Some calcite grains included within this fabric show a banded structure consistent with speleothem formation processes (Figure 9), most notably in MOX-34, MOX-31, and M46 [119,121]. This is consistent with the fact that there are karstic cave formations in the hillsides and ridges surrounding the Jovel Valley [97], including one that was used as a funerary cave at the site of Moxviquil [99]. Additionally, the Maya generally considered speleothems to be ritual objects and considered caves to be sacred [122]. Brady et al. [122] (p. 727) cite Dean Arnold with respect to modern Yucatecan communities using speleothems as temper, but argue that it was rare in pre-Hispanic times. Our petrographic results do suggest that speleothem tempering was occasionally (if rarely) practiced at the site of Moxviquil.

This fabric also contains mineral grains from volcanic sources, mainly quartz, feldspar, and amphibole, with rare pyroxene, which is consistent with the intermediate volcanic activity within the Chiapanecan Volcanic Arc [101]. These inclusions are typically smaller than the calcite clasts, usually coarse silt to fine sand sized, and it is likely that they were present in the clay deposits, rather than being added deliberately to the clay as temper. The density of inclusions is generally low, which is a significant difference from type C-2 (not discussed in this paper). The clay matrix is an orange brown, and is optically active, with moderate amounts of reddish and opaque iron oxide fragments. The similarities in calcite tempering material coupled with a nearly identical groundmass are sufficient to suggest that these sherds form a coherent fabric group. 


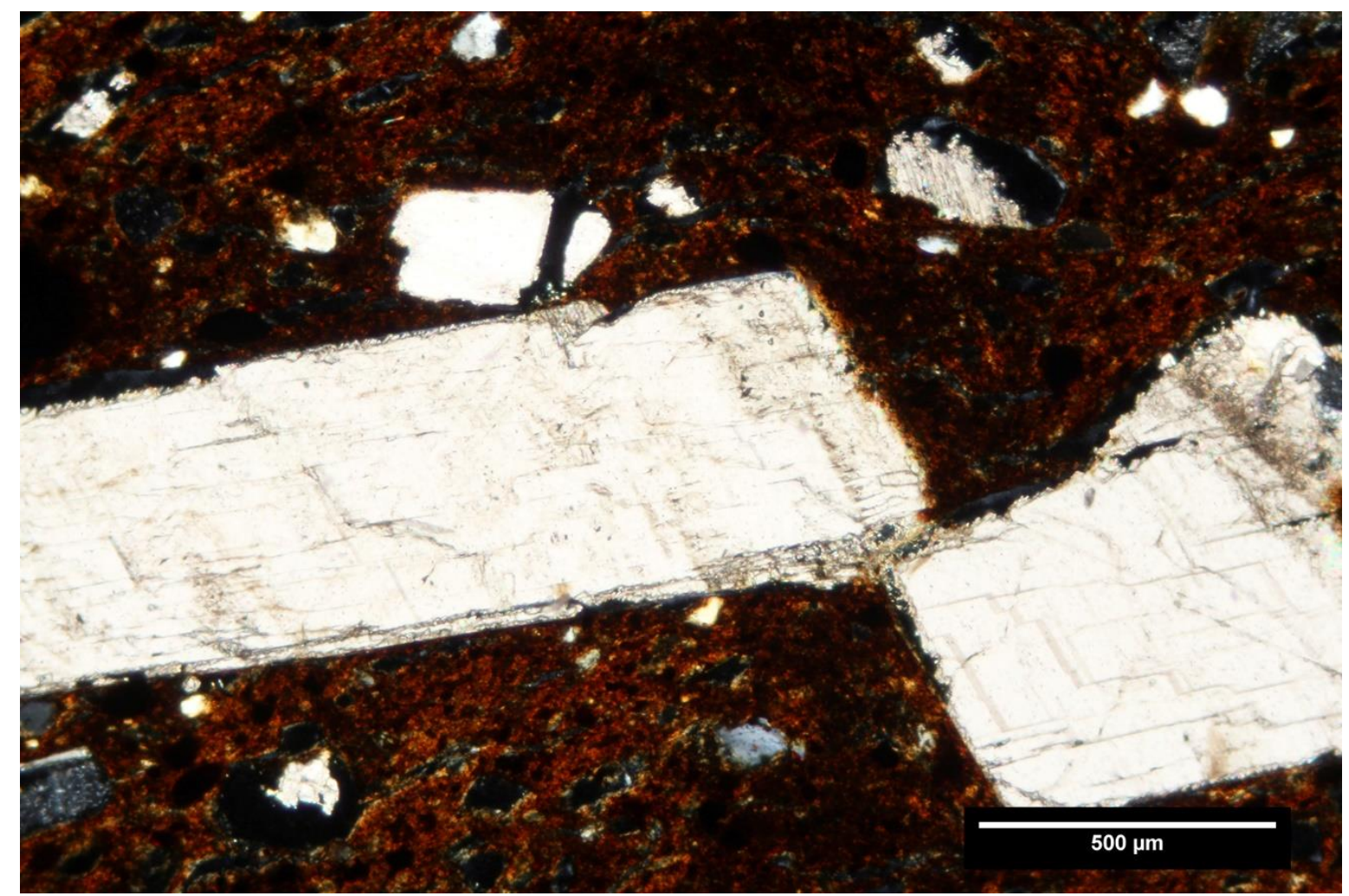

Figure 5. Typical view of large calcite crystals showing cleavage planes in fabric C-1 sample MOX-31. Photomicrograph taken under crossed polars by Jennifer Meanwell.

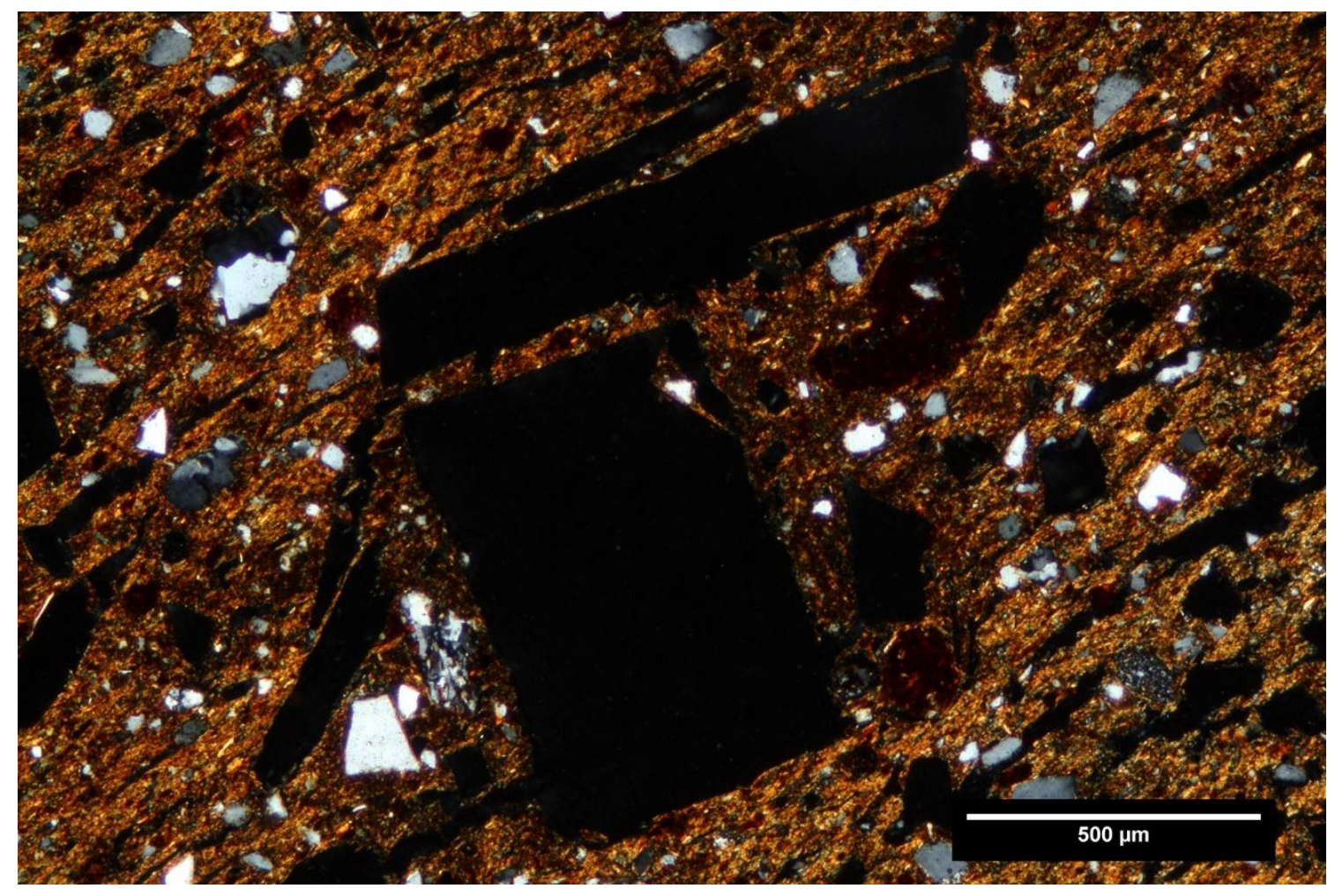

Figure 6. Large geometric voids left by the eroded calcite grains in sample MOX-32 from fabric C-1, also called calcite ghost voids. Note the similar groundmass and microstructure to Figure 4. Photomicrograph taken under crossed-polars by Jennifer Meanwell. 


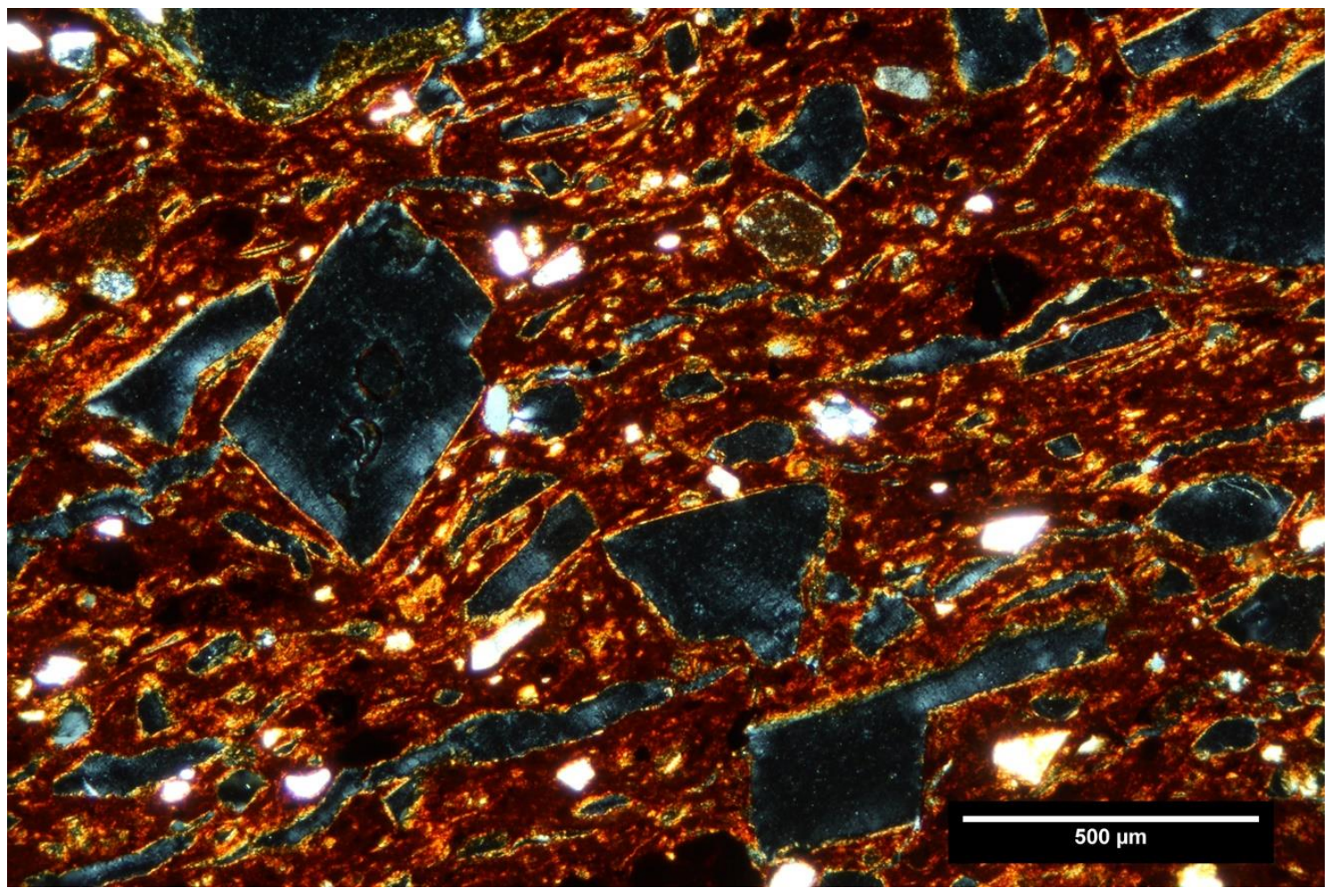

Figure 7. Photomicrograph of eroded calcite grain voids or calcite ghost voids in sample M40 from fabric C-1 that have calcareous material deposited around the edges of the pores. It is practically invisible in the thin section, except as bright lines of high birefringence around the pores. Photomicrograph taken under crossed-polars by Jennifer Meanwell.

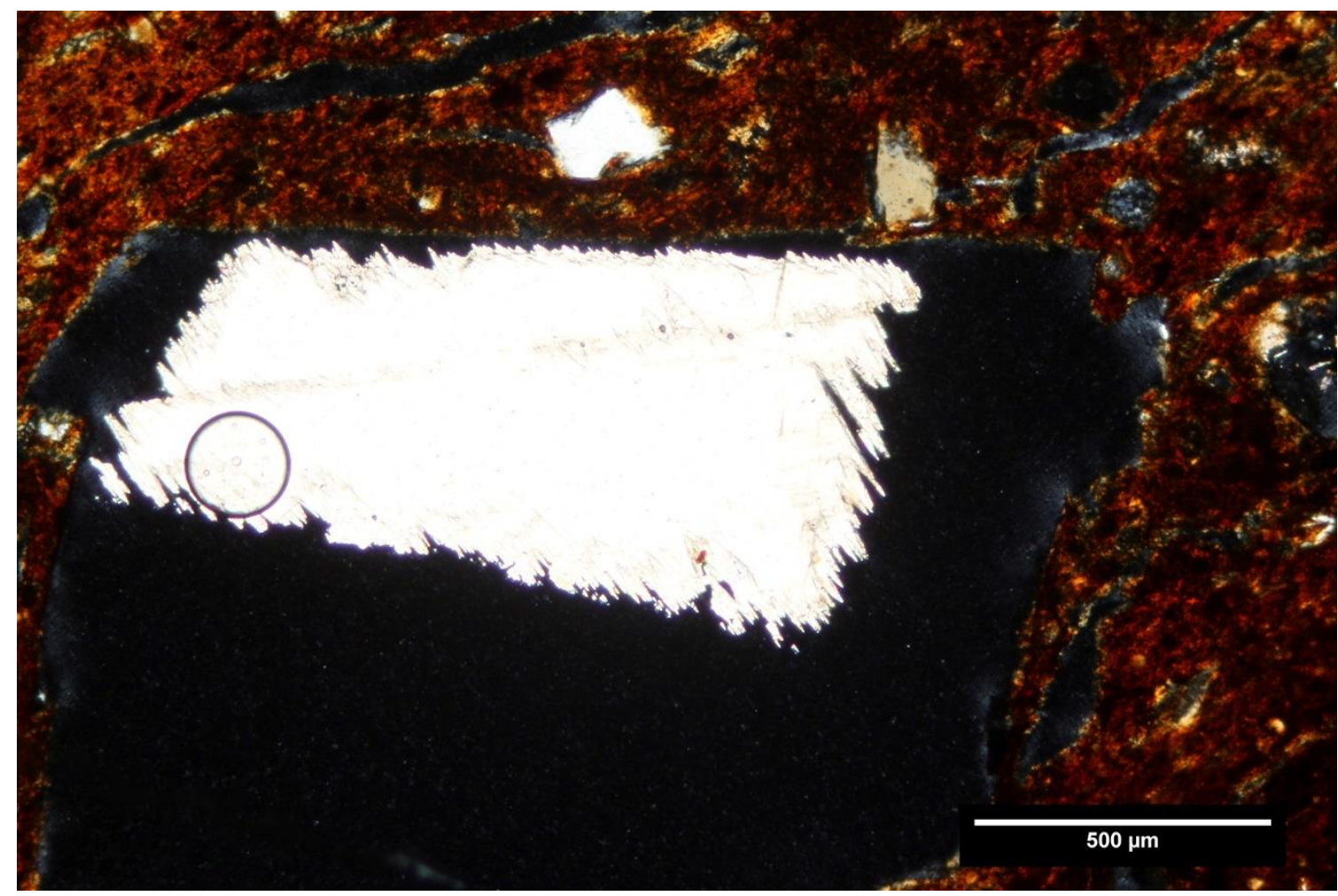

Figure 8. A large grain of partially eroded calcite within a pore in sample M50 from fabric C-1. Photomicrograph taken under crossed-polars by Jennifer Meanwell. 


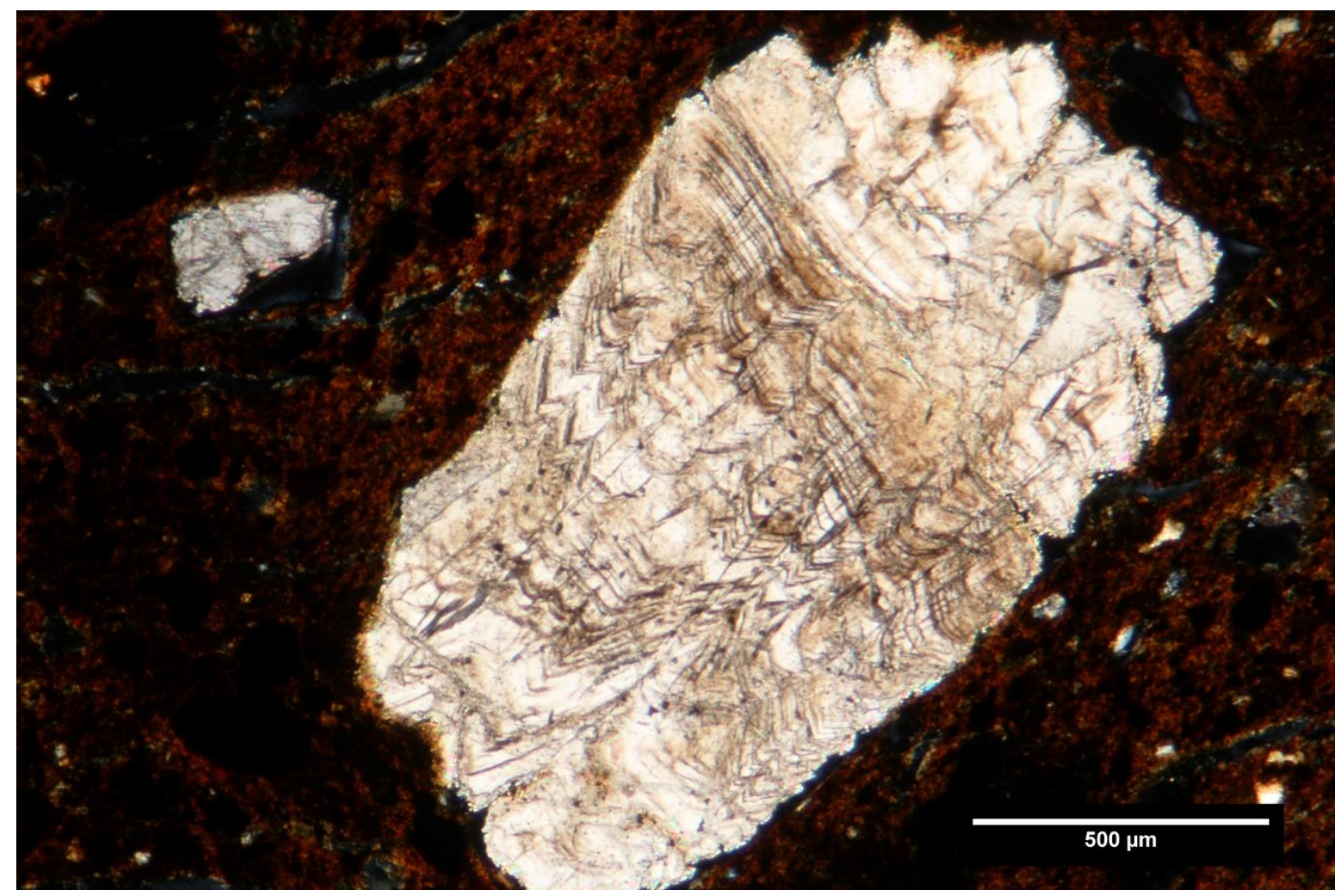

Figure 9. A large calcite grain within sample MOX-34 containing the banded deposition layers characteristic of speleothem formation processes. Photomicrograph taken under crossed-polars by Jennifer Meanwell.

Two other calcareous fabrics identified in thin section were noted in the collections from Moxviquil and CV-38. However, only five examples of the C-2 fabric and two examples of the C-3 fabric were among the set of 60 sherds analyzed chemically; they are not included in this paper because few were available for chemical analysis. The petrographic analysis also identified a single sherd (M50) with an atypical paste (classified as "OTHER"; see Table 1), which was also excluded from the chemical analysis. Observations from petrographic analysis tentatively suggest that these three fabrics were much less prone to calcite dissolution than fabric C-1. In all cases, sherds were sorted into the appropriate calcareous fabric whether or not the calcite or calcareous particles were still present. The size and shape of the voids left by calcite dissolution match precisely with the grains of calcite seen in less weathered samples. In many cases, the straight-line edges of the voids meet at the correct cleavage angles for calcite, further strengthening the argument that these sherds were all manufactured in the same way from the same material (Figures 6-8).

\subsubsection{SEM-EDS Results}

EDS analyses of the intact carbonate grains in available samples show a mean $\mathrm{Ca}$ concentration of 19.86 at\% (M46) and 31.7 at\% (M59), with 0.80 at\% or less Mg component in the grains. These concentration values combined with the $\mathrm{C}$ and $\mathrm{O}$ concentration values (Table 2) are consistent with quicklime $(\mathrm{CaO})$, or calcite $\left(\mathrm{CaCO}_{3}\right)$. Trace amounts of magnesium up to our observed $2.6 \mathrm{~mol} \%$ are consistent with a low-magnesian calcite [123]. This is important, as the dissolution rate of calcareous minerals in acidic environments is heavily dependent on the chemistry. Magnesian calcite is more soluble than calcite, which is more soluble than dolomite [123]. The chemical analysis could not completely eliminate the possibility that some grains of aragonite were also present in the sample, but aragonite is more soluble than pure calcite and less than high-magnesium magnesian calcite [123].

Point analyses of the clay matrix around the calcite grains suggests that some of the calcite may be dissolving and redepositing in the clay (Figure 10). The amount of 
magnesium present in the clay is consistent with the magnesium levels noted in the ICPMS/OES results to follow, suggesting that the grains of calcite are not the major source of magnesium in the samples (Table 2).

Table 2. Mean EDS elemental concentrations for assumed calcite grains and Ca leaching in M46 and M59. Data expressed in atomic percentages (at \%).

\begin{tabular}{|c|c|c|c|c|c|c|}
\hline & \multicolumn{2}{|c|}{ M46 } & \multicolumn{2}{|c|}{ M46 Ca Leach } & \multicolumn{2}{|c|}{ M59 } \\
\hline & Mean & SD & Mean & SD & Mean & SD \\
\hline C & 23.41 & 0.55 & 15.49 & 8.47 & 0.00 & 0.00 \\
\hline $\mathrm{O}$ & 51.44 & 1.52 & 51.26 & 9.96 & 63.98 & 19.99 \\
\hline $\mathrm{Na}$ & 0.00 & 0.00 & 1.56 & 1.30 & 0.11 & 0.20 \\
\hline $\mathrm{Mg}$ & 0.52 & 0.12 & 0.54 & 0.69 & 0.80 & 0.71 \\
\hline $\mathrm{Al}$ & 1.86 & 0.37 & 6.46 & 6.63 & 0.93 & 1.62 \\
\hline $\mathrm{Si}$ & 2.22 & 0.34 & 9.04 & 5.49 & 1.35 & 1.34 \\
\hline $\mathrm{Cl}$ & 0.06 & 0.02 & 0.00 & 0.00 & 0.00 & 0.00 \\
\hline $\mathrm{Ca}$ & 19.86 & 1.36 & 8.93 & 6.18 & 31.73 & 21.04 \\
\hline $\mathrm{Fe}$ & 0.42 & 0.03 & 4.86 & 4.38 & 0.06 & 0.10 \\
\hline $\mathrm{Ti}$ & 0.00 & 0.00 & 0.29 & 0.27 & 0.18 & 0.31 \\
\hline $\mathrm{K}$ & 0.00 & 0.00 & 0.46 & 0.63 & 0.25 & 0.34 \\
\hline $\mathrm{Mn}$ & 0.00 & 0.00 & 1.09 & 1.89 & 0.00 & 0.00 \\
\hline Total & 99.78 & & 99.98 & & 99.39 & \\
\hline
\end{tabular}

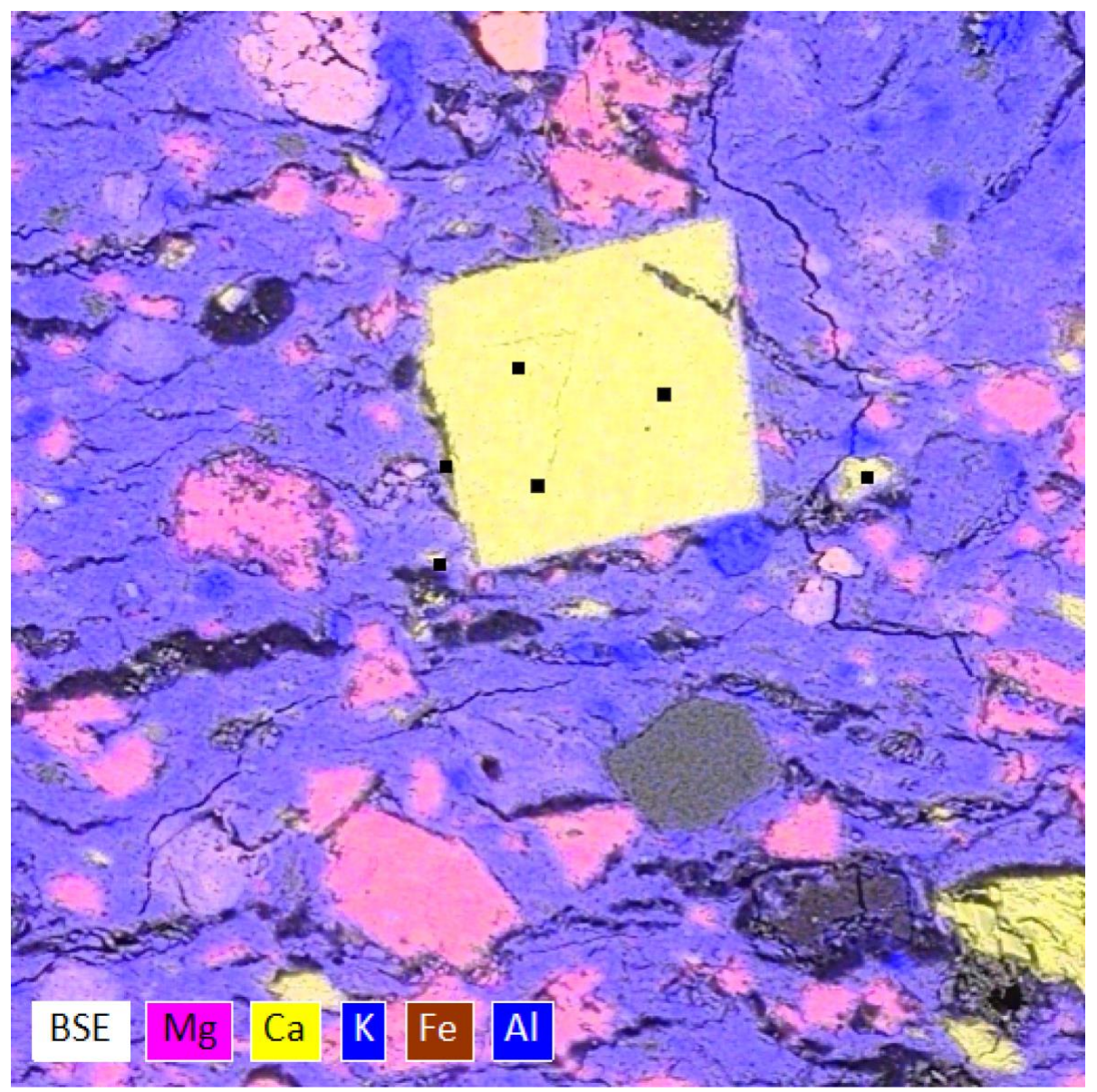

Figure 10. EDS elemental distribution map of a large calcite grain in sample M46. Black squares are locations of spot analyses for both the mineral grain and secondary calcite leaching. $\mathrm{Mg}$ and Fe concentrations are related to very small ferromagnesian minerals (amphiboles and pyroxenes) within the ceramic fabric. Ca distribution is noted only on calcite grains and clay matrix. Backscattered electron micrograph taken at $250 \times$ magnification by William Gilstrap. 


\subsubsection{ICP-MS/OES Results}

Resulting chemical concentrations for 9 sherds analyzed using ICP-MS/OES, representing petrographic fabric $\mathrm{C}-1$, show the most drastic variation mainly within measured alkali and alkaline earth elements: $\mathrm{Mg}, \mathrm{K}, \mathrm{Ca}, \mathrm{Rb}, \mathrm{Sr}, \mathrm{Cs}$ and $\mathrm{Ba}$ (Figure 11). Samples M31, M36, M40, and M41, from CV-38 and samples M49, and M50 from Moxviquil show depleted levels of all measured alkali and alkaline earth elements, with the exception of $\mathrm{Ba}$, as compared to the three remaining samples of fabric C-1 from Moxviquil (M46, M47, and M59). The differential preservation of calcite in the three intact Moxviquil samples may be due to their unusual excavation context, which was inside the funerary cave at the site near the former entrance [99]. The fact that calcite dissolution was seen in a variety of contexts from both sides of the valley is suggestive that acidic soils caused the calcite breakdown. It was expected that the samples with calcite ghost voids would have lower concentrations of $\mathrm{Ca}, \mathrm{Sr}$, and $\mathrm{Mg}$ as they represent the small subsample of fabric C-1 showing evidence for partial and complete calcite loss. Depletions of $\mathrm{K}, \mathrm{Rb}$, and $\mathrm{Cs}$ are to be expected as all are considered highly mobile elements in ceramic composition studies [41]. Indeed, it makes sense that these alkaline elements would be affected by the same naturally occurring corrosive processes that resulted in the calcite mineral loss.

In an attempt to see how much the variability was introduced by post-depositional calcite dissolution, we employed principal component analysis and omitted all alkali and alkaline earth elements. Additionally, several elements were omitted in which concentrations were below limits of detection ( $\mathrm{Li}, \mathrm{S}, \mathrm{Ni}, \mathrm{Sn}$ ) or are known to cause contamination problems due to modern agricultural activities in the region of interest (As, Pb). A comparison of the first two principal components illustrates well how much this post-depositional alteration process has obfuscated the likelihood that these samples used similar raw materials during production (Figure 12).

\subsubsection{Summary}

The internal chemical variation in fabric $\mathrm{C}-1$ is unexpected and has important implications for the interpretation of compositional data from archaeological ceramics. Analysis of the thin sections show that the group members of fabric C- 1 at Moxviquil and CV-38 are clearly composed of the near identical raw materials, the only visual difference under the petrographic microscope is the loss of calcite. Despite the petrographic similarities, the bulk chemical composition of C-1 samples from both sites varies significantly, even with the removal of problematic elements. Though it is apparent that when the calcite was dissolved by groundwater with a naturally low $\mathrm{pH}$, elements associated with calcite, $\mathrm{Ca}, \mathrm{Mg}$, $\mathrm{Sr}$, were not the only ones leached out into the local environment. Even the samples in which the calcite minerals were left intact demonstrate some level of disparity in all measured alkaline elements, suggesting that these too are affected by acidic groundwater. Without the integration of petrographic and chemical analyses, these discrepancies may never have been considered during the final archaeological interpretation of these ceramic data.

It could be argued that the Jovel Valley dataset should be compensated for the calcium loss employing the "calcium correction" factor [124]. This correction suggests that by adjusting the entire dataset through the following calculation:

$$
e=\frac{10^{6} e}{10^{6} 2.5 c}
$$

In which $e^{\prime}$ equals the corrected elemental value in ppm, $e$ is the measured elemental concentration in ppm and $c$ is the measured concentration of calcium in ppm. The gravimetric factor of 2.5 is used to compensate for the mass of calcium to calcium carbonate within the sample. In essence, this calculation attempts to remove any variability added by calcium carbonate inclusions that can potentially skew the entire dataset one way or another. There are two main reasons that this process will not be a useful correction factor in the Jovel Valley assemblage. The first is an anthropological argument that suggests that by removing the calcium carbonates in this way, the analysts are actually trying to 
mathematically remove physical temper from the dataset in order to get to what matters, the "raw materials," i.e., clay. Removing calcium carbonates in this way suggests that the carbonates themselves are not intrinsically part of the ceramic system being analyzed, though they are the result of human technological behaviors informed by social norms and material limitations. Ceramics, as we have argued above, are complex composite materials created by humans. They are cultural products and to remove a major part of their material essence is to remove valuable information concerning the choices past peoples made as they performed technological practices.

\section{Variability in Alkali and Alkaline Earth Elements in Jovel Valley Fabric C-1}

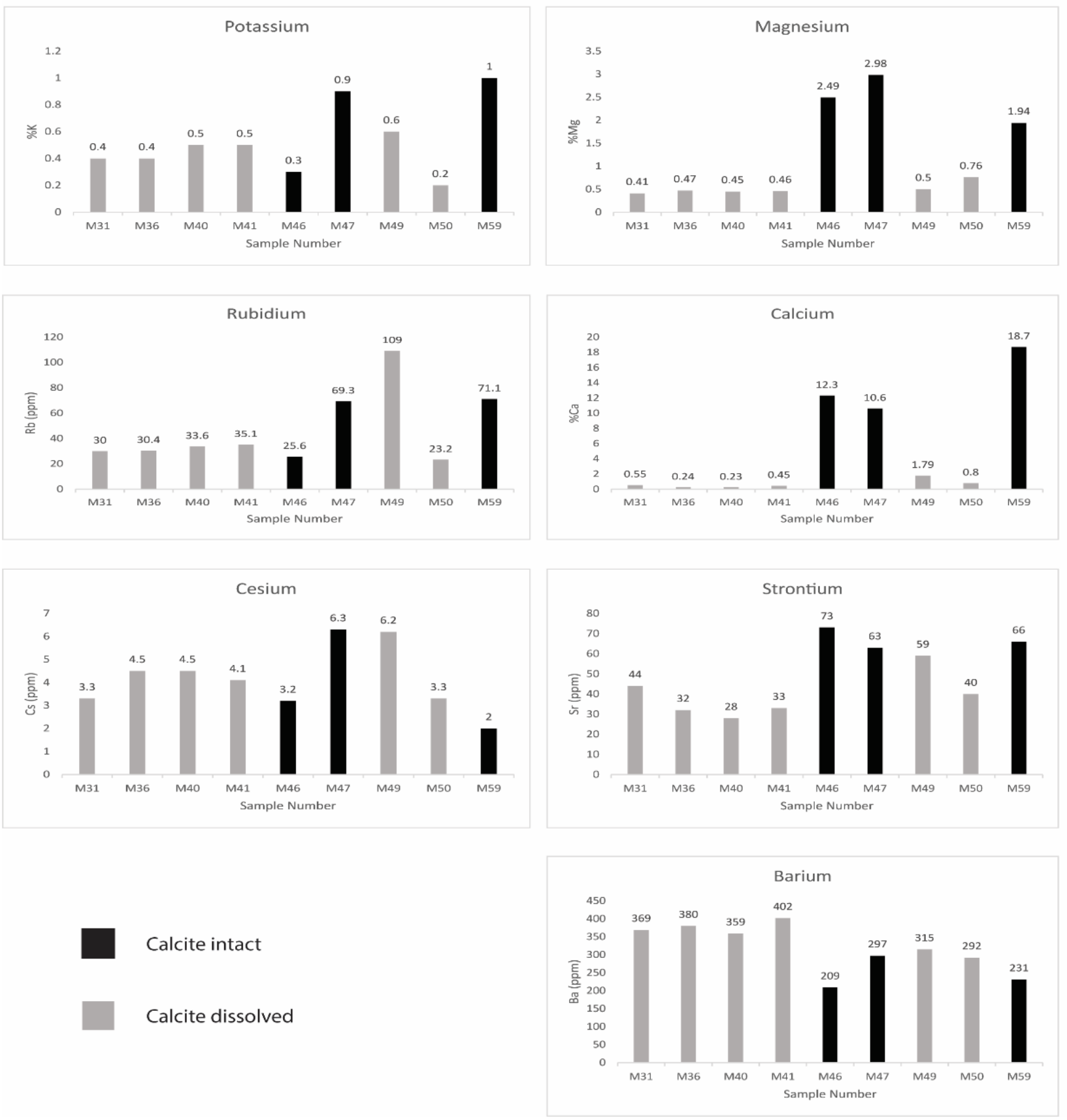

Figure 11. Graphs showing the concentration of various elements for C-1 samples both with and without intact calcite, at Moxviquil and CV-38. The stark contrast between the two groups is noticeable for multiple alkali and alkaline earth elements. 


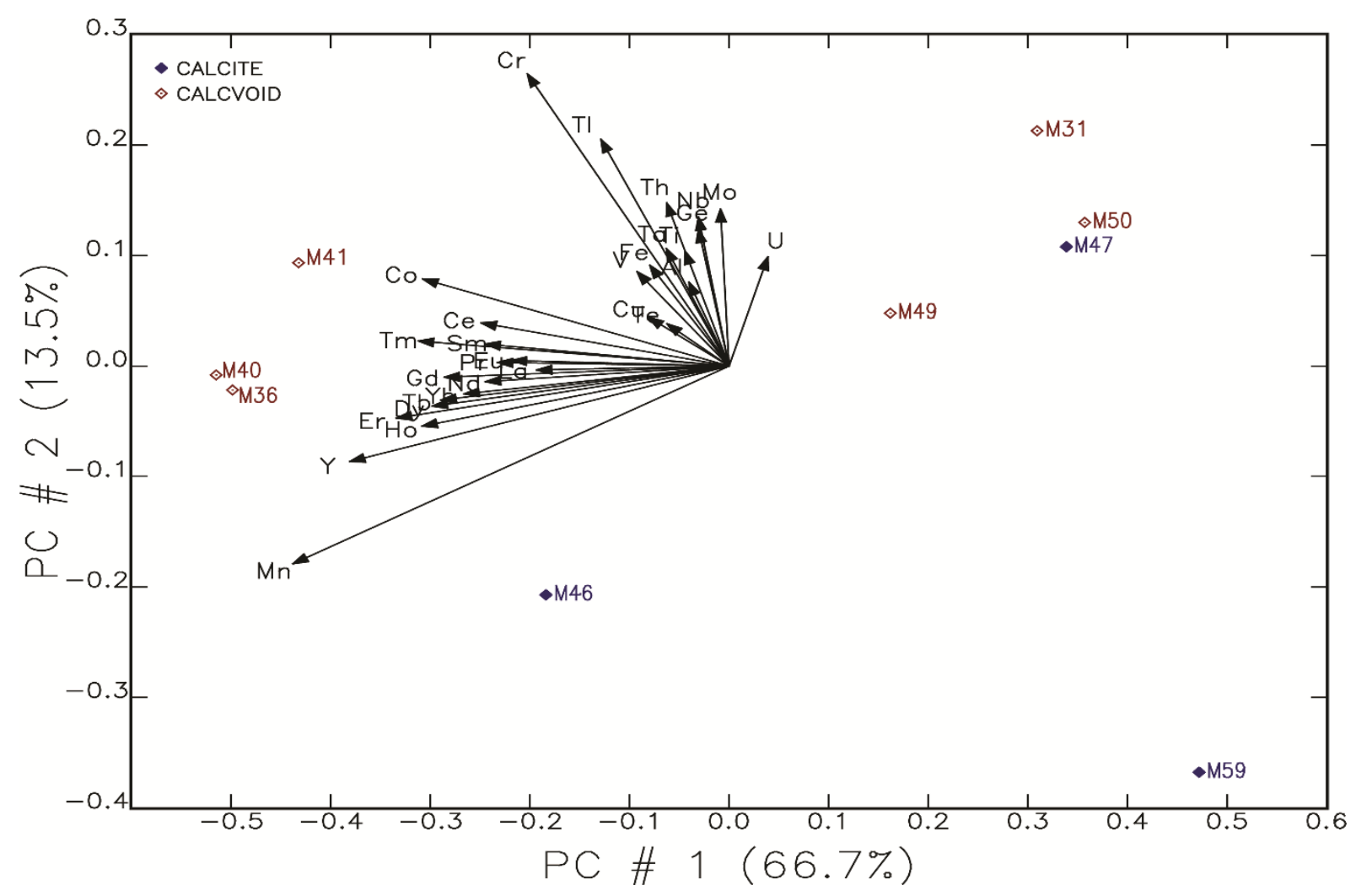

Figure 12. Scatterplot of the first two Principal Components, accounting for $70.2 \%$ of the total variance within petrographic fabric C-1, demonstrating the chemical heterogeneity caused by post-depositional alteration.

The second reason is that calcium is not the only element affected by the dissolution process. All alkaline elements were affected and to remove only one would not produce accurate or meaningful data. Logratio transformation using the element identified by TVM to have to lowest variability, in this case Ta, did not affect the final outcome, suggesting that the alteration is too great to overcome statistically.

\subsection{Case 2: Mycenaean Fineware Pottery: Calcite Redistribution}

The two fine tableware fabrics found in the greatest abundances are produced by potting groups at Kontopigado, SAR-1, and in northeast Corinthia, SAR-11, perhaps near Ancient Corinth. Both SAR-1 and SAR-11 are manufactured using calcareous clays, however, potters at Kontopigado used a mixture of calcareous marls and terra rossa clays, while Corinthian potters appeared to have selected calcareous clays as the main raw materials. Previous assessments of their microstructures by SEM-EDS confirm that SAR-1 contains a low-moderate calcareous matrix of $4-6 \% \mathrm{CaO}$ and sintering levels suggestive of firing in oxidizing conditions at temperatures of over $850^{\circ} \mathrm{C}$ [111]. SAR- 11 has a much higher concentration of $\mathrm{CaO}$ of over $11 \%$ and significant enough sintering within the microstructure to estimate firing in oxidizing conditions at temperatures between $850{ }^{\circ} \mathrm{C}$ and $1000{ }^{\circ} \mathrm{C}$ [116] (p. 175). These results are compatible with petrographic observations of fabric matrices as both SAR-1 and SAR-11 are optically inactive. Firing temperature is particularly relevant, as high fired ceramics will form high temperature minerals that can capture calcium (making it unavailable for dissolution) and also make the fabric less porous and, therefore, hinder post-depositional leaching processes. Although SAR- 1 and SAR-11 are not the only fine tableware ceramic fabrics present in the Saronic Gulf during the end of the Late Bronze Age, they are both produced with calcareous raw materials and fired to moderately high temperatures. They are similarly shaped and decorated and are often found together in the same excavation contexts [111,116]. Lastly, the presence of PA 
secondary calcite is profound in many petrographic specimens from this region, a feature that is common in Aegean archaeological ceramics.

\subsubsection{SAR 1}

SAR 1 is the main fabric used for pottery manufacture at the site of Kontopigado, approximately $5 \mathrm{~km}$ south of the Athenian acropolis (Figure 13) [111] (pp. 502-505). It is constructed using a fine clay mix whose groundmass consists of fine sand sized mica laths, quartz and feldspar with inclusions of low grade metamorphic and sedimentary rock both in the groundmass and coarse fraction. The lithic inclusions are likely natural constituents of the clay-rich sediments selected as raw materials and are highly compatible with rock types common in northern and central Attica, especially the formation of Attic Schist [125]. The last major component is a greyish-yellow calcareous sediment, visible in the form of textural concentration features [51] (p. 386) most likely from the yellowish marl deposits near the coastal town of Ayios Kosmas.

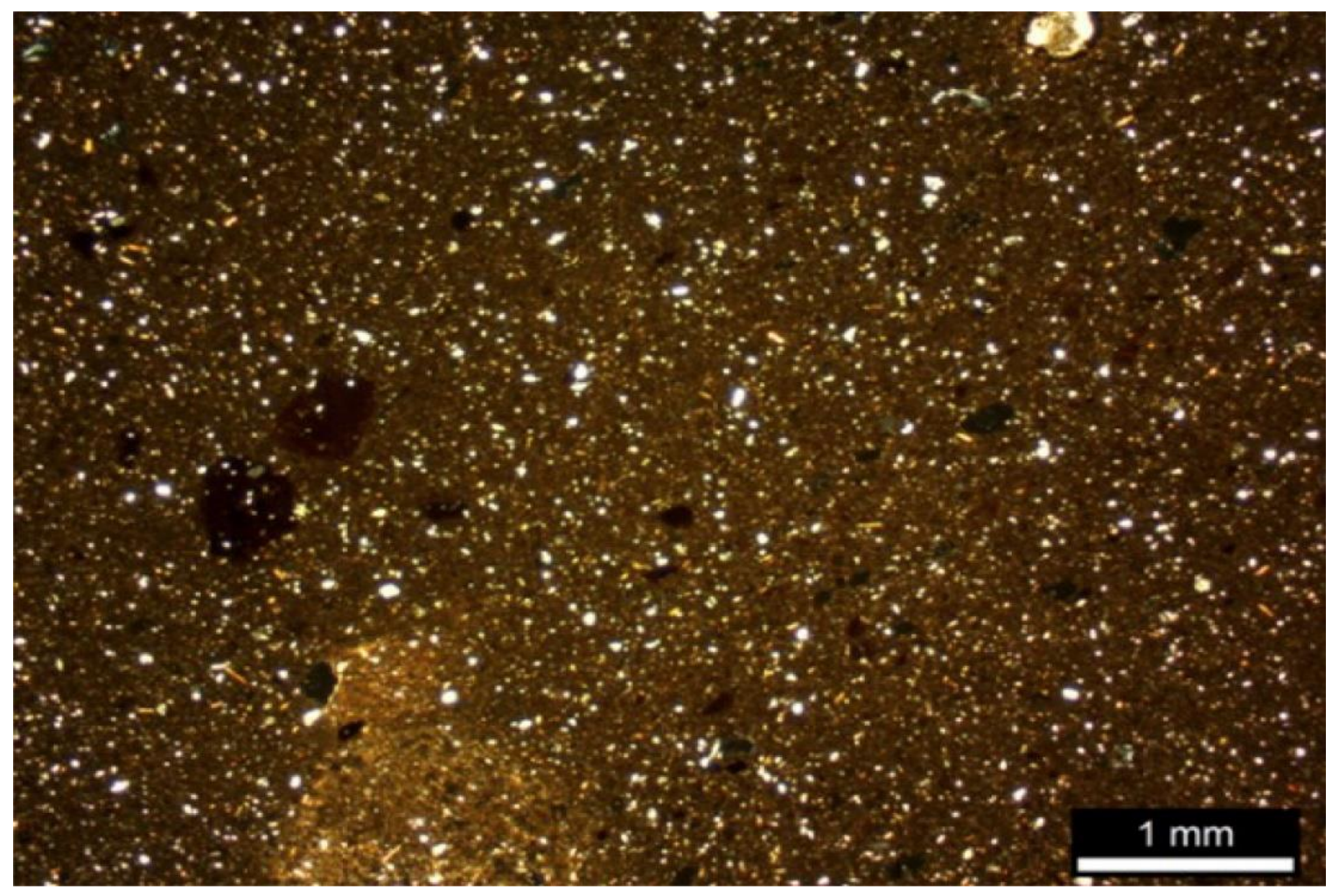

Figure 13. Photomicrograph of sample ALM 12/32, a typical SAR 1 composition under crossed polars. Yellowish feature in the lower left of the image is part of an incompletely homogenized marl. Image by William Gilstrap.

Within the microstructure, microgeodetic sparite is frequently observed on the boundaries of pore walls and internal cracks. Void structures are commonly filled in partially or completely with microgeodetic sparite, cryptocrystalline calcite (micrite) or a combination of the two (Figure 14). Striations or patches of aggregated micrite are, however, the most frequent type of alteration observed. The structure of these micro- and cryptocrystalline calcite deposits is taken as evidence of a combination of at least PA post-depositional alteration of carbonate matter in this fabric. 


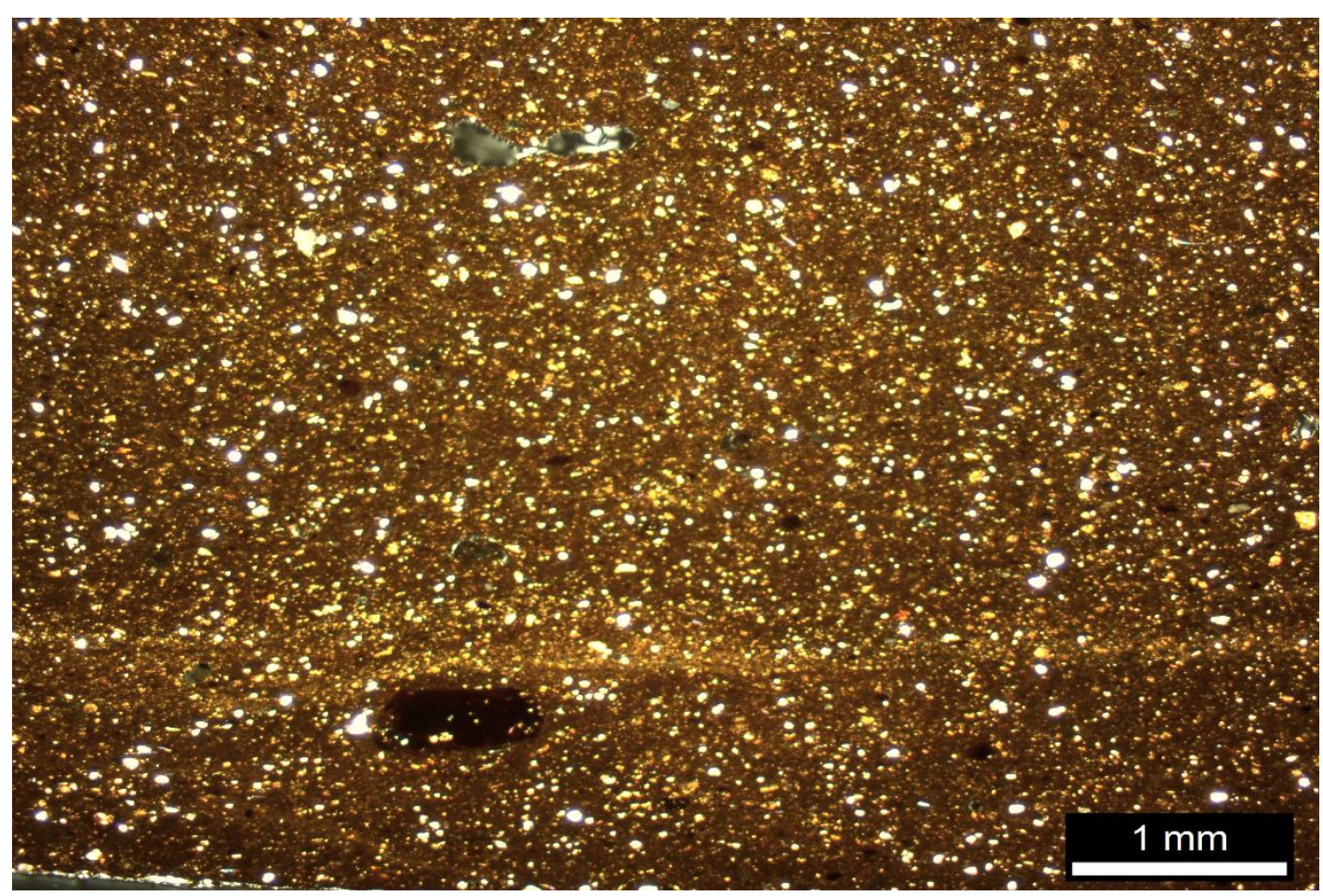

Figure 14. Photomicrograph of sample ELF 12/17 under crossed polars. Note small aggregates of yellowish micrite spread throughout the micromass and long yellowish domain in the lower third of the image. Image by William Gilstrap.

\subsubsection{SAR 11}

Ceramic fabric SAR-11 is very fine, with very few inclusions over $0.5 \mathrm{~mm}$, and was used to produce high-quality drinking and wine mixing vessels (Figure 15). The fine grain size of the inclusions inhibits the identification of a production region; however, there are rare but notable serpentinite, calcareous microfossils, siliceous radiolarian microfossils and calc-silicate sandstone particles present in the coarse sand grain fraction. These inclusions are highly compatible with the Shale-Sandstone-Radiolarite formations of Corinthia [125]. Sedimentary formations are present throughout both Corinthia and the Argolid, but the Shale-Sandstone-Radiolarite formations of Corinthia are known to be exploited by Corinthian potters from prehistory through the historical periods, suggesting a plausible production origin at Corinth [126]. Based on the compatibility of this fabric's mineralogical composition with the geological formations local to northeast Corinthia, in addition to the uncanny resemblance to Early Bronze II pottery fabrics produced at or near ancient Corinth [127], SAR 11 is understood to be a product of a potting center within this region, probably near Ancient Corinth.

Many of these sherds were recovered from surface deposits with clear macroscopic evidence for carbonate accretions. The microstructure of this fabric commonly contains pores partially or completely infilled with microgeodetic sparite, micrite or a combination of the two. The micromass shows frequent striations and/or patches of aggregated micrite (Figure 16). 


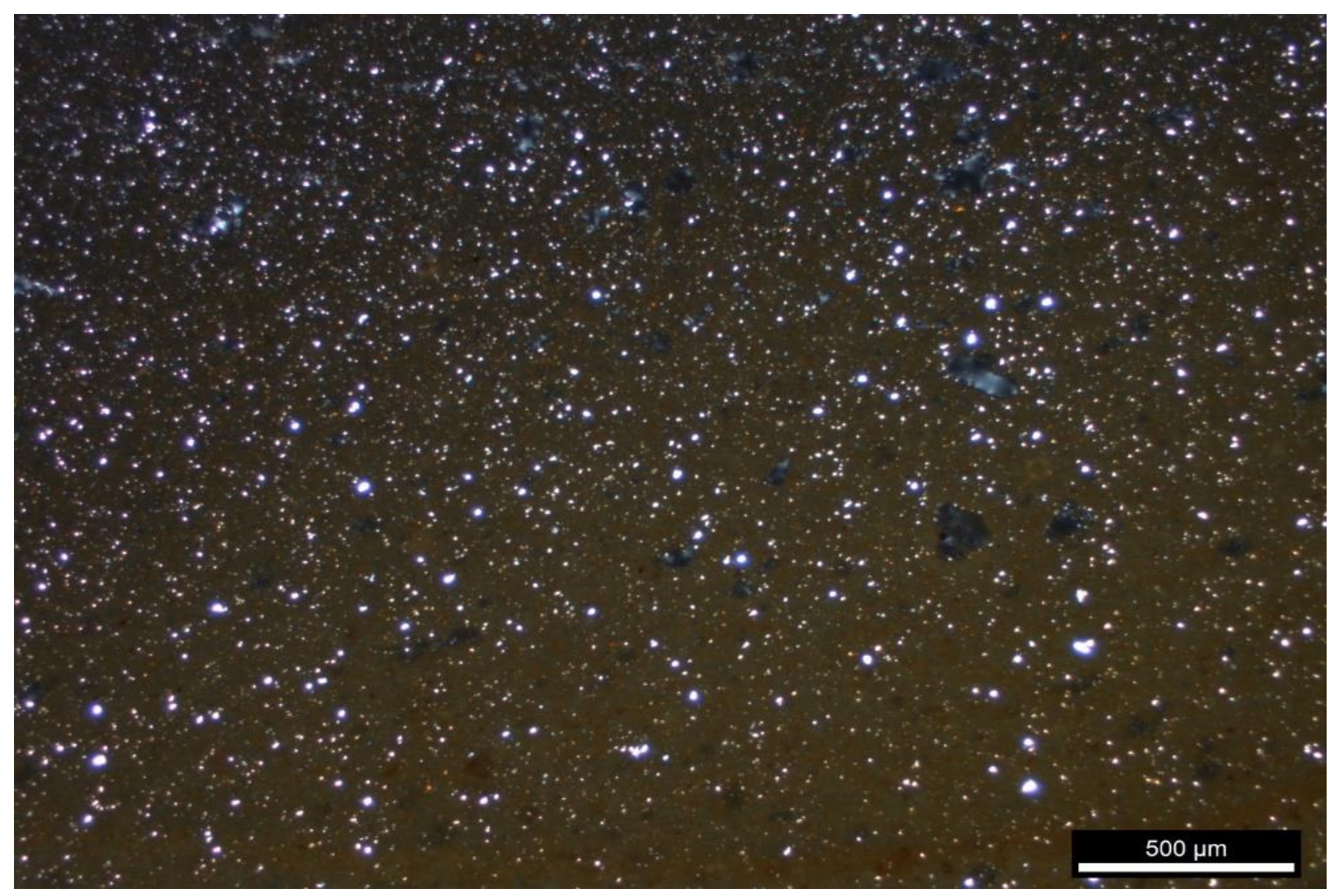

Figure 15. Photomicrograph of a typical sample (AK12-63) in SAR 11 showing an unaltered groundmass under crossedpolars. Image by William Gilstrap.

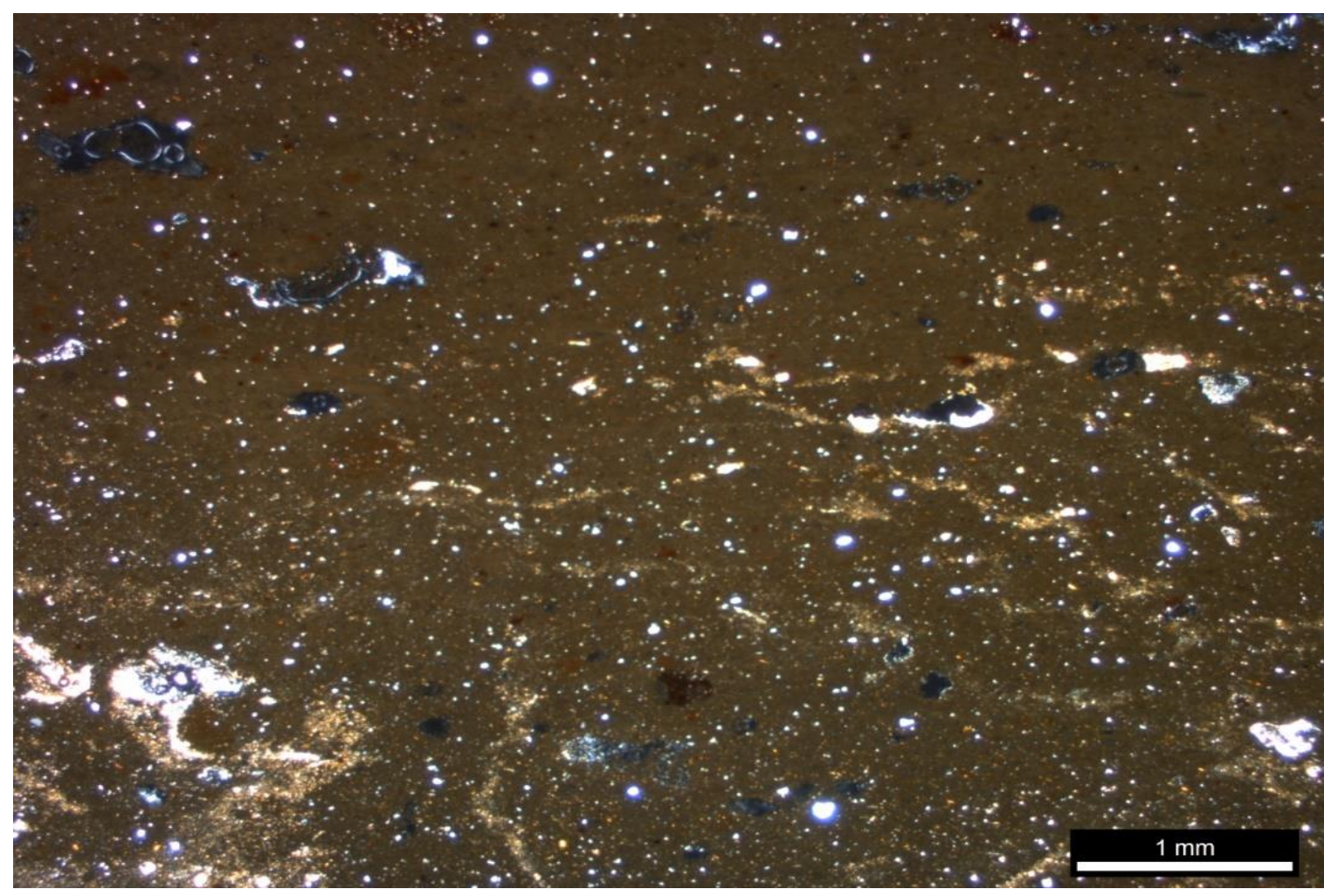

Figure 16. Photomicrograph of fabric SAR 11 under crossed-polars, demonstrating post-depositional alteration of carbonate matter observed as micritic patches and striations within groundmass (ELF 12/14). Image by William Gilstrap. 


\subsubsection{Effect of Post-Depositional Calcite Alterations on Bulk Chemical Analysis}

The presence of post-depositional calcite observed in several specimens from each petrographic fabric group is considerable. However, not every member of affected petrographic fabrics demonstrates evidence of calcite alteration as the groups are composed of ceramic fragments recovered from at least eight different burial environments, each enabling varying degrees of calcite alteration to occur. The fabric groups selected to test if post-depositional calcite alteration affects elemental concentrations enough to cause errors in traditional methods of cluster analysis are the two of the most dominant fabrics identified in the study region with 133 (SAR1/Group 1) and 69 (SAR 11/Group 3) samples.

Chemical Group 1 reflects the main ceramic fabrics produced at the Attic production center of Kontopigado in western Attica, specifically SAR 1 (Table 3). Although the standard deviations for over half of the 22 elements analyzed are $12 \%$ or less, several elements, including $\mathrm{Rb}, \mathrm{Ba}, \mathrm{Ca}, \mathrm{Cs}$, and $\mathrm{Zn}$, have higher standard deviations (from 17 to $35 \%$; Table 3). The fluctuation is indicative of post-depositional alterations that occur in coastal marine environments where alkalis are selectively leached, as has been shown in ceramic studies of the kiln material at Kommos, Crete $[89,127]$. As and Sb are known transient elements and their values must be carefully evaluated, although these two elements appear consistent within this group. Enriched concentrations of $\mathrm{Co}(>30 \mathrm{ppm})$ and $\mathrm{Cr}$ ( $>600 \mathrm{ppm})$, especially when combined with high $\mathrm{Ni}$ concentrations, are usually indicative of ophiolite-derived grains and ophiolitic soils, but this phenomenon also occurs in a variety of metamorphic environments [128]. Co, $\mathrm{Cr}$ and $\mathrm{Zn}$ concentrations can vary more broadly in soils than rocks [128] (p. 117), perhaps explaining higher variation in $\mathrm{Cr}$ and $\mathrm{Zn}$.

Table 3. Mean compositional concentrations for elements measured in Chemical Groups 1 and 3. All data are reported in ppm unless otherwise stated.

\begin{tabular}{|c|c|c|c|c|c|c|}
\hline \multicolumn{4}{|c|}{ Chemical Group 1} & \multicolumn{3}{|c|}{ Chemical Group 3} \\
\hline Element (ppm) & Mean & SD & SD (\%) & Mean & SD & SD (\%) \\
\hline $\mathrm{Ca}(\%)$ & 5.11 & 1.4 & 28.0 & 11.02 & 2.9 & 26.6 \\
\hline Sc & 21.00 & 1.3 & 6.2 & 18.9 & 2.3 & 12.1 \\
\hline $\mathrm{Cr}$ & 645.70 & 113.4 & 17.6 & 218 & 27.4 & 12.6 \\
\hline $\mathrm{Fe}(\%)$ & 5.41 & 0.5 & 10.0 & 4.92 & 0.6 & 12.2 \\
\hline Co & 35.60 & 4.3 & 12.0 & 26.3 & 3.1 & 11.6 \\
\hline $\mathrm{Zn}$ & 126.20 & 29.4 & 23.3 & 110.8 & 19.7 & 17.8 \\
\hline $\mathrm{Rb}$ & 113.60 & 20.0 & 17.6 & 117.3 & 20.9 & 17.8 \\
\hline $\mathrm{Zr}$ & 110.60 & 17.9 & 16.2 & 90.6 & 18.1 & 20 \\
\hline Cs & 14.60 & 5.2 & 35.7 & 7.7 & 1.5 & 19.3 \\
\hline $\mathrm{Ba}$ & 526.00 & 165.7 & 31.5 & 408.9 & 151.8 & 37.1 \\
\hline $\mathrm{La}$ & 28.80 & 3.2 & 11.1 & 30.1 & 3 & 10 \\
\hline $\mathrm{Ce}$ & 61.90 & 6.8 & 10.9 & 59.4 & 6 & 10.2 \\
\hline Sm & 5.75 & 0.5 & 8.9 & 5.32 & 0.5 & 9.4 \\
\hline $\mathrm{Eu}$ & 1.14 & 0.1 & 8.6 & 1.11 & 0.1 & 8.9 \\
\hline $\mathrm{Tb}$ & 0.71 & 0.1 & 19.3 & 0.66 & 0.1 & 16.3 \\
\hline $\mathrm{Yb}$ & 2.54 & 0.2 & 9.0 & 2.42 & 0.2 & 10.3 \\
\hline $\mathrm{Lu}$ & 0.37 & 0.0 & 9.8 & 0.36 & 0.04 & 11.8 \\
\hline Hf & 4.52 & 0.5 & 10.7 & 3.42 & 0.4 & 12.8 \\
\hline $\mathrm{Ta}$ & 0.92 & 0.1 & 10.0 & 0.85 & 0.1 & 12.7 \\
\hline Th & 9.88 & 1.1 & 10.9 & 9.96 & 1.2 & 12.2 \\
\hline $\mathrm{U}$ & 2.34 & 0.4 & 17.7 & 2.23 & 0.4 & 16.9 \\
\hline
\end{tabular}

The mean calcium concentration value for Group 1 is $5.11+/-1.4 \%$. The statistical variance of calcium for this particular group is rather high at $28 \%$, but this does not appear to affect group membership. For example, the sample ELF 12/17 (Figure 17) has a Ca concentration value of $6.4 \%$, yet it has a group membership probability value $(p)$ 79.53. Group membership probabilities are calculated as described by Glascock [117] and Neff [128] and a $p$ value of 79.53 indicates a $79.53 \%$ probability of membership within 
chemical Group 1. Combined with the petrographic data, it is clear that this sample has been altered from its original composition likely with some enrichment of Ca. That this sample was recovered from the site of Eleusis, which sits on alluvial deposits derivative of transgressive limestones and marls [125], suggests that it perhaps accrued some CA calcite through aqueous solutions transporting dissolved calcite as it moved through the calcareous sediments and limestone environment. These calcite accretions do not appear to have much of an effect on the resulting compositional grouping. A large sample size of 133 group members may be large enough that some variance in migratory alkaline elements are not great enough to override the consistencies in REE and trace elemental concentrations.

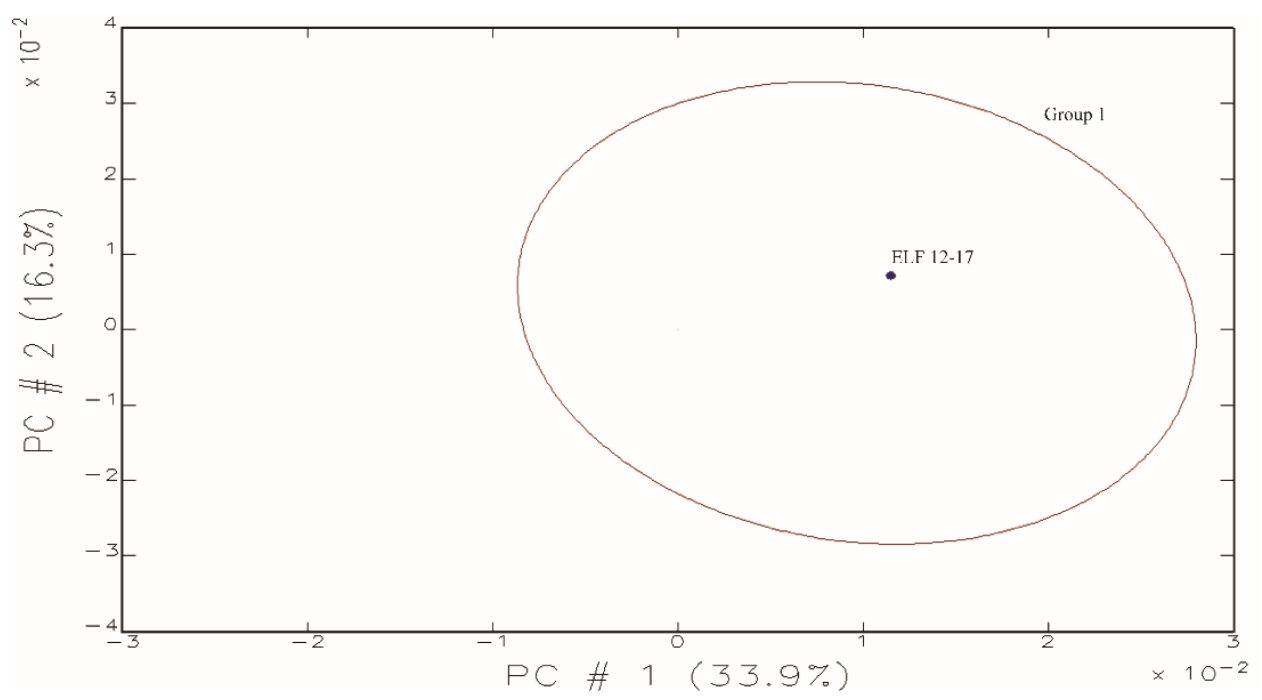

Figure 17. Scatterplot comparing PC 1 and PC 2 from the Saronic Gulf Core Group 1 [95] assemblage demonstrating the location of ELF 12/17 in Group 1. Image by William Gilstrap.

Chemical Group 3 (Table 3) is a quite tightly clustered group with the majority of the group members showing over $30 \%$ probability of group membership and the majority of elemental standard deviations are below $15 \%$. The group is characterized by enriched mean values of $\mathrm{Ca}(11.06+/-2.9 \%), \mathrm{Cs}(7.7+/-1.5 \mathrm{ppm})$ and $\mathrm{Rb}(117.3+/-20.9 \mathrm{ppm})$, and depleted in $\mathrm{Cr}(218.19+/-27.4 \mathrm{ppm})$ and $\mathrm{Co}(26.3+/-3.1 \mathrm{ppm})$. Variation is found in concentrations of $\mathrm{Ba}(408.9+/-151.8)$ and $\mathrm{Zr}(90.6+/-18.1 \mathrm{ppm})$. The majority of the samples in this group come from the western Saronic coast, namely Corinthia and the Methana peninsula. When compared to petrographic results, it is clear that Group 3 represents the fabric group SAR 11. Comparison with regional chemical reference groups did not produce any potential matches to help identify production origins. Petrographic analysis, on the other hand, suggests a Corinthian origin near Ancient Corinth [126].

Many of the sherds comprising Group 3 show severe calcite alteration as demonstrated by Figure 15. Such a high degree of alteration present in the groundmass supports the hypothesis that this sample, or others like it, would not chemically match its petrographic counterparts. The sample in question, ELF 12/14, was recovered from a coastal burial deposit in the southeastern coast of the Isthmus of Corinth. This area, as above, is composed mainly of limestone and calcareous sediments, a prime area for calcium leaching to occur. However, this sample shows a Ca concentration value of $10.05 \%$, nearly identical to the mean group Ca concentration values $(11.03+/-2.9 \%)$ and similarly consistent elemental concentrations across the board. It is unlikely that the Ca accretions on the exterior or the alteration products in the groundmass affected the elemental composition of this sample at all (Figure 18). 


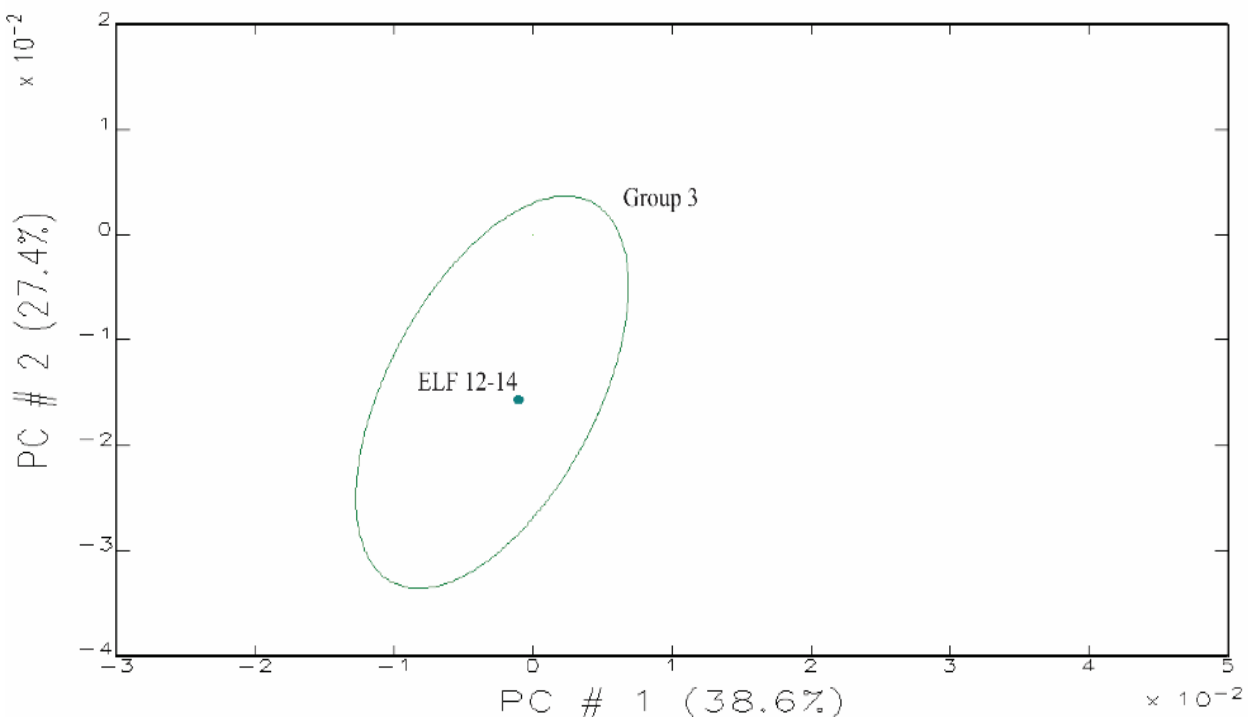

Figure 18. Scatterplot comparing PC 1 and PC 2 from the Saronic Gulf Core Group 3 [95] assemblage demonstrating the location of ELF 12/14 within Group 3. Image by William Gilstrap.

\subsubsection{Summary}

The case of the Saronic Gulf assemblage provides clear evidence that calcite alteration occurs during the post-depositional phase of archaeological ceramics, especially within marine and calcareous burial environments. The alterations are most visible in thin section under a petrographic microscope. In fact, the alteration products can be so persistent that it can be quite difficult to observe and describe the microstructure or groundmass of a ceramic system in its unaltered form. A large sample size helps mitigate this issue, as does sampling from a variety of culturally interconnected contexts. As clear as the redeposition of calcite is within the Saronic Gulf assemblage, it does not appear to have much of a problematic effect on the overall elemental composition. By extension, this means that researchers experiencing this issue can trust their compositional measurements and provenance-based interpretations.

However, it may be that calcite dissolution occurred during the post-depositional period prior to recovery, but it was not leached out of the ceramic system. Rather, it appears that the calcite recrystallized as micrite and/or sparite within the ceramic groundmass. If this is indeed the case, it would appear that calcite alteration in the form of micro- and crypto-crystalline redeposition within a ceramic structure occurred within a closed system. By this, we mean that the calcite alterations observed in this case study were the product of acidic groundwater penetration of the ceramic material system causing dissolution of alkaline matter such as calcite, but it did not cause the calcite to leach out of the system and into the environment.

The only case to our knowledge which has a convincing and serious allochthonous contribution to post-burial alterations of chemical compositions is the over-fired waster fragments from the Late Minaon IA pottery kiln at Kommos, Crete [90]. This case revealed that alkaline element concentrations were altered differentially according to the firing temperature of the pottery. Pottery fired at higher temperatures was impacted by the formation minerals, such as Na-zeolites (e.g., analcime). The presence of Na-zeolites is linked to crystallization of free minerals left by the alteration of the glassy phase in overfired pottery calcareous pottery $[20,47,129]$. Buxeda and his colleagues [90] indicate that $\mathrm{K}$, and to a lesser extent $\mathrm{Rb}$, are also leached during alteration of the glassy phase and affixing of the Na component, however they do not see the same affects in Cs concentrations, attributing its different behavior to its larger atomic size [90] (p. 364).

In the case of the sample ELF 12/17 and the rest of the respective ELF (Eleusis) assemblage, it appears that some calcite may have been transported into the ceramic system from the burial environment by groundwater, but it was not enough to alter its 
bulk composition to the degree that it would change the outcome of the cluster analysis used to form reference groups. The second sample, ELF 12/14 has ample evidence for carbonate alteration in the groundmass; however, it does not appear to affect the chemical composition enough to nullify its group membership in fabric SAR 11. The alterations identified in both examples examined in this study likely reflect a redistribution of preexisting carbonate matter from within their respective ceramic systems.

\section{Conclusions}

Archaeological ceramic artifacts, once discarded, are subject to the same environmental weathering processes as the associated geological materials including sediments and bedrock formations. In fact, the burial stage of an artifact's "life history" is the longest and sometimes the most arduous phase of its entire existence. Ceramic materials decay and may undergo chemical and physical alterations that change the nature of the microstructure, and in some cases, their bulk elemental profile. The Jovel Valley study illustrates the extreme case for complete mineral dissolution of calcite grains used as a tempering material in their ceramic products. More significantly, it shows that when calcite grains dissolve, there is reason to believe that other alkaline elements commonly used in ceramic composition studies can be affected as well. In this case, the effects were so great that even with the removal of the noticeably affected elements from the cluster analyses, members of the fabric groups $\mathrm{C}-1$ with and without remaining calcite grains were not identified as chemically compatible.

In the Jovel Valley pottery, the pronounced loss of alkaline elements, with the exception of $\mathrm{Ba}$, is probably more pronounced due to the loss of large grains of the calcite minerals being removed from within a noncalcareous clay matrix. The depletions of $\mathrm{K}$ and $\mathrm{Rb}$ are not linked to firing temperature and the related formation of zeolites, as the high degree of optical activity in the micromass testifies to their low firing temperature. Variability in Cs is constant across all presented C-1 samples, but the concentrations are consistent within the samples showing calcite dissolution. $\mathrm{Mg}$ and $\mathrm{Sr}$, elements closely related to calcite mineral composition, appear to correlate with the loss of $\mathrm{Ca}$ as well. These samples were not made from different raw materials or constructed using different technological practices, rather, their chemical variation is empirically linked to the decomposition of calcite due to local environmental factors.

At the other end of the spectrum, the Saronic Gulf assemblage corroborates other studies' findings [42] that carbonate matter can be altered and redistributed through a single ceramic material system post-burial. Here, it seems that the internally extant carbonate matter of a well-sintered ceramic sherd does react with naturally low $\mathrm{pH}$ groundwater seeping through its porous microstructure. This is evident from the recrystallization of micro- and cryptocrystalline calcite in the groundmass. However, unlike in the case of the Jovel Valley sherds, calcite is merely redeposited within the sample, thereby causing no noticeable effects on the chemical composition. Rather, it only appears to alter the microstructural textures visible through ceramic petrography.

The calcareous components from the Saronic Gulf assemblage are derived from the fine, clay-bearing sediments and were part of a well-sintered, moderately high-fired ceramic system. The Jovel Valley fabric C-1 is formed from noncalcareous clays with large crystalline calcite added as a tempering agent in a poorly sintered, low-fired ceramic system. This leads us to understand that carbonate grainsize and firing temperatures achieved during production are crucial factors to consider, beyond the specific conditions of the burial environments, during compositional examinations of ancient ceramic materials.

The situational nature of post-depositional calcite alteration and the effect it has on bulk compositional studies is evident. Therefore, we should anticipate the potential for alteration of these ceramics in the burial environment. Thin section petrography clearly has a key role to play in identifying leaching and secondary calcite formation, along with other processes of alteration and contamination, which may affect our interpretation of bulk chemical composition in studies of provenance and technology. This study suggests 
that the effects are complex, and rather varied. As our compositional data in studies of archaeological ceramics are derived from the destruction of materials that are by nature a finite resource, our increased understanding of these taphonomic alterations enable us to make the most of the material under our stewardship.

Supplementary Materials: The following are available online at https://www.mdpi.com/article/10 $.3390 / \mathrm{min} 11070749 / \mathrm{s} 1$, Table S1: Sample information for Samples in SAR-1 and Chemical Group 1 of Case Study 2; Table S2: Sample information for Samples in SAR-11 and Chemical Group 3 of Case Study 2

Author Contributions: Conceptualization, W.D.G. and J.L.M.; Methodology, W.D.G. and J.L.M.; Software, W.D.G.; validation, W.D.G. and J.L.M.; Formal Analysis, (Petrography) W.D.G. and J.L.M., (ICP-MS) W.D.G., (NAA) W.D.G.; Investigation, W.D.G. and J.L.M.; Resources, W.D.G., J.L.M., E.H.P., R.L.B., and P.M.D.; Data Curation, W.D.G. and J.L.M.; Writing-Original Draft Preparation, W.D.G. and J.L.M.; Writing-Review and Editing, W.D.G., J.L.M., E.H.P., and P.M.D.; Visualization, W.D.G., J.L.M., and E.H.P.; Supervision, W.D.G.; Project Administration, W.D.G., E.H.P., R.L.B., and P.M.D.; Funding Acquisition, W.D.G., J.L.M., E.H.P., R.L.B., and P.M.D. All authors have read and agreed to the published version of the manuscript.

Funding: The Jovel Valley samples were excavated and exported with generous permission from the Consejo de Arqueología, Instituto Nacional de Antropología e Historia (INAH), as part of the "Proyecto Económico de los Altos de Chiapas," directed by Elizabeth H. Paris and Roberto López Bravo, with export permits received in 2016 and 2018. The project received support from a National Science Foundation Doctoral Dissertation Improvement Grant (2009; Award ID 0836590), and a Wenner-Gren Foundation International Collaborative Research Grant (2015-2016; \#ICRG-127). The directors also received support from the University of Calgary, Universidad de Ciencias y Artes de Chiapas, ProNatura Chiapas, Centro INAH-Chiapas, the Museo Na Bolom, and the New World Archaeological Foundation for the project. ICP-MS analyses were funded by the Center for Materials Research in Archaeology and Ethnology (CMRAE) research funds. The Saronic Gulf samples were studied as part of the corresponding author's doctoral research conducted with funding from the European Union, FP7, Marie Curie Actions ITN entitled “New Archaeological Research Network for Integrating Approaches to ancient material studies" (NARNIA, Project no. 265010), with support in the analysis of pottery from Kanakia from the Institute for Aegean Prehistory. For permits to study and samples pottery, we thank the Ephorates of Attica, Piraeus and Islands and Corinthia, in addition to the Directorate of Conservation of the Ministry of Culture. For permission to study and sample pottery for our broader study we thank Michael Cosmopoulos, Walter Gauss, Elina Kardamaki, Konstantina Kaza-Papageorgiou, Eleni Konsolaki, Yannos Lolos, Christina Marabea, Apostolos Papadimitriou, Daniel Pullen, Jerry Rutter, Naya Sgouritsa and Tom Tartaron.

Data Availability Statement: Data are available upon request. Data are not being made public as they form part of larger research projects that are not yet published in their entirety.

Conflicts of Interest: The authors declare no conflict of interest.

\section{References}

1. Neff, H. Good, Fast, Cheap; pick any two: Characterization of ceramic materials. In Ceramics in Archaeology: Readings from Am. Antiq., 1936-2002; Neff, H., Ed.; Society for American Archaeology: Washington, DC, USA, 2005; pp. 209-214.

2. Krieger, A.D. The Typological Concept. Am. Antiq. 1944, 9, 277-288. [CrossRef]

3. Rouse, I. On the Typological Method. Am. Antiq. 1944, 10, 202-204. [CrossRef]

4. Spaulding, A.C. Statistical Techniques for the Discovery of Artifact Types. Am. Antiq. 1944, 18, 305-313. [CrossRef]

5. Sabloff, J.A.; Smith, R.E. The Importance of Both Analytic and Taxonomic Classification in the Type-Variety System. Am. Antiq. 1969, 34, 278-285. [CrossRef]

6. Dunnell, R.C. Sabloff and Smith's. The Importance of Both Analytic and Taxonomic Classification in the Type-Variety System. Am. Antiq. 1971, 36, 115-118. [CrossRef]

7. Ford, J.A. A Chronological Method Applicable to the Southeast. Am. Antiq. 1938, 3, 260-264. [CrossRef]

8. Rowe, J.H. Stratigraphy and Seriation. Am. Antiq. 1961, 26, 324-330. [CrossRef]

9. Dunnell, R.C. Seriation Method and Its Evaluation. Am. Antiq. 1970, 35, 305-319. [CrossRef]

10. Shennan, S.J.; Wilkinson, J.R. Ceramic Style Change and Neutral Evolution: A Case Study from Neolithic Europe. Am. Antiq. 2001, 66, 577-593. [CrossRef] 
11. Asaro, F.; Perlman, I. Provenience studies of Mycenaean pottery employing neutron activation analysis. In Acts of the International Archaeological Symposium: The Mycenaeans in the Eastern Mediterranean; Department of Antiquities: Nicosia, Cyprus, 1973; pp. 213-224.

12. Feathers, J.K. Explaining Shell-Tempered Pottery in Prehistoric Eastern North America. J. Archaeol. Method Theory 2006, 13, 89-113. [CrossRef]

13. Hein, A.; Kilikoglou, V. Compositional variability of archaeological ceramics in the eastern Mediterranean and implications for the design of provenance studies. J. Archaeol. Sci. Rep. 2017, 16, 564-572. [CrossRef]

14. Jones, R.E. Pottery as Evidence for Trade and Colonisation in the Aegean Bronze Age: The Contribution of Scientific Techniques. In Wace and Blegen: Pottery as Evidence for Trade in the Aegean Bronze Age 1939-1989, Proceedings of the International Conference held at the American School of Classical Studies, Athens, Greece, 2-3 December 1989; Zerner, C., Zerner, P., Winder, J., Eds.; J. C. Gieben: Amsterdam, The Netherlands, 1993; pp. 11-17.

15. Miksa, E.J.; Heidke, J. It All Comes Out in the Wash: Actualistic Petrofacies Modeling of Temper Provenance, Tonto Basin, Arizona, USA. Geoarchaeology 2001, 16, 177-222. [CrossRef]

16. Neff, H. Neutron Activation Analysis for Provenance Determination in Archaeology. In Modern Analytical Methods in Art and Archaeology; Ciliberto, E., Spoto, G., Eds.; John Wiley and Sons: New York, NY, USA, 2000; pp. 81-134.

17. Steponaitis, V.; Blackman, M.J.; Neff, H. Large-Scale Patterns in the Chemical Composition of Mississippian Pottery. Am. Antiq. 1996, 61, 555-572. [CrossRef]

18. Stoltman, J. A Quantitative Approach to the Petrographic Analysis of Ceramic Thin Sections. Am. Antiq. 1989, 54, 147-160. [CrossRef]

19. Stoner, W.D.; Glascock, M.D. The forest or the trees? Behavioral and methodological considerations for geochemical characterization of heavily-tempered ceramic pastes using NAA and LA-ICP-MS. J. Archaeol. Sci. 2014, 39, 2668-2683. [CrossRef]

20. Buxeda i Garrigós, J. Minoanising pottery traditions in the SW Aegean: Understanding the social context of technological and consumption practices. J. Archaeol. Sci. 1999, 26, 295-303. [CrossRef]

21. Shaw, J.W.; Van de Moortel, A.; Day, P.M.; Kilikoglou, V. A LM IA Ceramic Kiln in South-Central Crete: Function and Pottery Production. Hesperia Suppl. 2001, 30.

22. Day, P.M.; Kiriatzi, E.; Tsolakidou, A.; Kilikoglou, V. Group Therapy in Crete: A Comparison between Analyses of NAA and Thin Section Petrography of Early Minoan Pottery. J. Archaeol. Sci. 1999, 26, 1025-1036. [CrossRef]

23. Druc, I.C. Portable Digital Microscope-Atlas of Ceramic Pastes: Components, Texture and Technology; Deep University Press: Madison, WI, USA, 2015.

24. Gosselain, O.P. Bonfire of the Inquiries. Pottery firing temperatures in Archaeology: What for? J. Archaeol. Sci. 1992, 19, 243-259. [CrossRef]

25. Kilikoglou, V.; Vekinis, G.; Maniatis, Y. Toughening of ceramic earthenwares by quartz inclusions: An ancient art revisited. Acta Metall. Mater. 1995, 43, 2959-2965. [CrossRef]

26. Kilikoglou, V.; Vekinis, G.; Maniatis, Y.; Day, P.M. Mechanical performance of quartz-tempered ceramics. Part I: Strength and toughness. Archaeometry 1998, 40, 261-279. [CrossRef]

27. Matson, F.R. Technological Ceramic Studies. Collage Art J. 1942, 1, 25-28. [CrossRef]

28. Matson, F.R. Ceramics and Man; Aldine Publishing Co.: Chicago, IL, USA, 1965.

29. Meanwell, J.L.; Paris, E.H.; Peraza Lope, C.; Seymour, L.; Masic, A. Blowpipes and their metalworking applications: New evidence from Mayapán, Yucatán, Mexico. PLoS ONE 2020, 15, e0238885. [CrossRef]

30. Meanwell, J.L.; Paris, E.H.; Cruz Alvarado, W.; Peraza Lope, C. Metallurgical ceramics from Mayapán, Yucatán, Mexico. J. Archaeol. Sci. 2013, 40, 4306-4318. [CrossRef]

31. Müller, N.S.; Kilikoglou, V.; Day, P.M.; Vekinis, G. The influence of temper shape on the mechanical properties of archaeological ceramics. J. Eur. Ceram. Soc. 2010, 30, 2457-3465. [CrossRef]

32. Müller, N.S.; Kilikoglou, V.; Day, P.M.; Vekinis, G. Thermal shock resistance of tempered archaeological ceramics. In Craft and Science: International Perspectives on Archaeological Ceramics; Martinón-Torres, M., Ed.; Bloomsbury Qatar Foundation: Doha, Qatar, 2014; pp. 263-270.

33. Maniatis, Y.; Tite, M.S. Ceramic Technology in the Aegean World. In Thera and the Aegean World; Doumas, C., Ed.; The Thera Foundation: London, UK, 1978; pp. 483-492.

34. Maniatis, Y.; Tite, M.S. Technological Examination of Neolithic-Bronze Age Pottery from Central and Southeast Europe and from the Near-East. J. Archaeol. Sci. 1981, 8, 59-76. [CrossRef]

35. Ownby, M.F. The Importance of Petrography for Interpreting Compositional Data A Case Study of Tanque Verde Red-on-Brown. In Integrative Approaches in Ceramic Petrography; Ownby, M.F., Druc, I.C., Masucci, M.A., Eds.; University of Utah Press: Salt Lake City, UT, USA, 2016; pp. 24-28.

36. Shepard, A.O. The technology of Pecos pottery. In Pottery of Pecos. Vol. 2, Papers of the Southwestern Expedition, Vol. 7; Phillips Academy, New Haven, Department of Archaeology: Andover, MA, USA, 1936; pp. 389-587.

37. Shepard, A.O. Ceramics for the Archaeologist; Carnegie Institution of Washington Publication: Washington, DC, USA, 1965.

38. Schiffer, M.B.; Skibo, J.M. Theory and Experiment in the Study of Technological Change. Curr. Anthropol. 1987, $28,595-622$. [CrossRef] 
39. Skibo, J.M.; Butts, T.C.; Michael, B.S. Ceramic Surface Treatment and Abrasion Resistance: An Experimental Study. J. Archaeol. Sci. 1997, 24, 311-317. [CrossRef]

40. Rice, P.M. Pottery Analysis: A Sourcebook; University of Chicago Press: Chicago, IL, USA, 1986.

41. Buxeda i Garrigós, J.; Mommsen, H.; Tsolakidou, A. Alterations of Na, K, and Rb in Mycenaean pottery and a proposed explanation using x-ray diffraction. Archaeometry 2002, 44, 187-198. [CrossRef]

42. Cau Ontiveros, M.A.; Day, P.M.; Montana, G. Secondary calcite in archaeological ceramics: Evaluation of contamination and alteration processes by thin section study. In Modern Trends in Scientific Studies on Ancient Ceramics; Kilikoglou, V., Hein, A., Maniatis, Y., Eds.; Papers presented at the 5th annual European Meeting on Ancient Ceramics, Athens 1999; BAR International Series 1011; Archaeopress: Oxford, UK, 2002; pp. 8-18.

43. Golitko, M.; Dudgeon, J.V.; Neff, H.; Terrell, J.E. Identification of post-depositional chemical alteration of ceramics from the north coast of Papau New Guinea (Sanduan Province) by time-of-flight-laser ablation-inductively coupled plasma-mass spectrometry (TOF-LA-ICP-MS). Archaeometry 2012, 54, 80-100. [CrossRef]

44. Golitko, M.A.; McGrath, A.; Kreitler, I.V.; Lightcap, P.R.; Duffy, G.M.; Parditka, G.M.; Giblin, J.I. Down to the Crust: Chemical and Mineralogical Analysis of Ceramic Surface Encrustations on Bronze Age Ceramics from Békés 103, Eastern Hungary. Minerals 2021, 11, 436. [CrossRef]

45. Maggetti, M. Phase Analysis and its Significance for Technology and Origin. In Archaeological Ceramics; Olin, J.S., Franklin, A.D., Eds.; Smithsonian Institution Press: Washington, DC, USA, 1982; pp. 121-133.

46. Mommsen, H. Provenance determination of pottery by trace element analysis: Problems, solutions and applications. J. Radioanal. Nucl. 2001, 247, 657-662. [CrossRef]

47. Picon, M. Remarques préliminaires sur deux types d'altération de la composition chimique des céramiques au cours du temps. Figlina 1976, 1, 159-166.

48. Picon, M. Quelques observations complémentaires sur les altérations de composition des céramiques au cours du temps: Cas de quelques alcalins et alcalino-terreux. Rev. D'archeometrie 1991, 15, 117-122. [CrossRef]

49. Neff, H.; Cogswell, J.W.; Ross, L.M.J. Supplementing bulk chemistry in archaeological provenance investigations. In Patterns and Process: A Festschrift in Honor of Dr. Edward V. Sayre; van Zelst, L., Ed.; Smithsonian Center for Materials Research and Education: Suitland, MD, USA, 2003; pp. 220-224.

50. Whitbread, I.K. A proposal for the systematic descriptions of thin sections towards the study of ancient ceramic technology. In Archaeometry; Maniatis, Y., Ed.; Elsevier: Amsterdam, The Netherlands, 1989; pp. 127-138.

51. Whitbread, I.K. Greek Transport Amphorae: A petrological and Archaeological Study. Fitch Laboratory Occasional Paper 4; British School at Athens: Athens, Greece, 1995.

52. Kemp, R.A. Soil micromorphology and the Quaternary. Quaternary Research Association Technical Guide 2; Cambridge, UK, 1985.

53. Vekinis, G.; Kilikoglou, V. Mechanical performance of quartz-tempered ceramics: Part II, Hertzian strength, wear resistance and applications to ancient ceramics. Archaeometry 1998, 40, 281-292. [CrossRef]

54. Hein, A.; Müller, N.S.; Day, P.M.; Kilikoglou, V. Thermal conductivity of archaeological ceramics: The effects of inclusions, porosity and firing temperature. Thermochim. Acta 2008, 480, 35-42. [CrossRef]

55. Müller, N.S.; Hein, A.V.; Kilikoglou, P.M. Day Modelling thermal stresses in Prehistoric cooking ware. In Proceedings of the 5th Conference of the Hellenic Society for Archaeometry (2008); Zacharias, N., Georgakopoulou, M., Polykreti, K., Fakorellis, G., Bakoulis, T., Eds.; Papazisi Editions: Athens, Greece, 2012; pp. 477-491.

56. Allegretta, I.; Eramo, G.; Pinto, D.; Hein, A. The effect of mineralogy, microstructure and firing temperature on the effective thermal conductivity of traditional hot processing ceramics. Appl. Clay Sci. 2017, 135, 260-270. [CrossRef]

57. Roux, V. Ceramics and Society: A Technological Approach to Archaeological Assemblages; Springer: New York, NY, USA, 2019.

58. Skibo, J.M. Pottery Function: A Use-Alteration Perspective; Springer: New York, NY, USA, 1992.

59. Schiffer, M.B.; Skibo, J.M.; Griffitts, J.L.; Hollenbeck, K.L. Behavioral archaeology and the study of technology. Am. Antiq. 2001, 66, 729-737. [CrossRef]

60. Meanwell, J.L. Technical requirements and technical choices in pottery production: A view from the Middle Balsas Region of Guerrero, Mexico. Am. Antiq. 2015, 80, 312-331. [CrossRef]

61. Carter, C.B.; Norton, M.G. Ceramic Materials: Science and Engineering; Springer: New York, NY, USA, 2007.

62. Kingery, W.D.; Bowen, H.K.; Uhlmann, D.R. Introduction to Ceramics, 2nd ed.; John Wiley and Sons: New York, NY, USA, 1976.

63. Halek, V.; Novak, M. Problems concerning solution of steady and unsteady groundwater flow by statistical methods. Dev. Soil Sci. 1972, 2, 101-118.

64. Courtois, L. Examen au microscope pétrographique des céramiques archéologiques. Centre de Recherches Archéologiques. In Notes et Monographies Techniques No. 8; Centre National de la Recherche Scientifique: Paris, France, 1976.

65. Schneider, G. Anwendung quantitativer Materialanalysen auf Herkunftsbestimmunen antiker Keramik. Berl. Beiträge zur Archäometrie 1978, 3, 63-122.

66. Schneider, G. Mineralogical and Chemical Alteration. In The Oxford Handbook of Archaeological Ceramic Analysis; Alice, M.W.H., Ed.; Oxford University Press: Oxford, UK, 2006; pp. 162-180.

67. Olin, J.S.; Harbottle, G.; Sayre, E.V. Elemental Compositions of Spanish and Spanish-Colonial Majolica Ceramics in the Identification of Provenience. In Archaeological Chemistry II. Advances in Chemistry Series 171; Carter, G.F., Ed.; American Chemical Society: Washington, DC, USA, 1978; pp. 200-229. 
68. Olin, J.S.; Sayre, E.V. Environmental and Technological Causes of Variations in the Absolute Concentrations of Elements in Ceramics. In Proceedings of the 18th International Symposium on Archaeometry (Bonn), Archaeophysika, Bonn, Germany, 14-17 March 1978; Volume 10, p. 607.

69. Heimann, R.B.; Maggetti, M. Experiments on simulated burial calcareous Terra Sigillata (mineralogical change). Preliminary results. In Scientific Studies in Ancient Ceramics. British Museum Occasional Paper 19; Hughes, M.J., Ed.; British Museum: London, UK, 1981; pp. 163-177.

70. Maggetti, M.; Westley, H.; Olin, J.S. Provenance and Technical Studies of Mexican Majolica Using Elemental and Phase Analysis. Archaeol. Chem. III 1984, 151-191. [CrossRef]

71. Joyner, L.; Day, P.M. Appendix: Petrographic Fabric Descriptions, in D.E. Wilson and P.M. Day EMIIB ware groups at Knossos: The 1907-1908 South Front tests. Annu. Br. Sch. Athens. 1999, 94, 1-62.

72. Echallier, J.C. Premières données pétrographiques sur les amphores massaliètes du Languedoc. Lett. d'information du CRA 21 Archéologie du Midi Médéitrranéen 1983, 9, 68-73.

73. García Heras, M. Deposiciones invisibles: Microprocesos de calcitización postdeposicional en cerámicas celtibéricas. Arqueol. Espac. 1993, 16-17, 391-406.

74. Walter, V. Étude Pétrographique, Minéralogique Et Géochimique D'amphores Gauloises Découvertes Dans Le Nord-est De La France; Thèse de Doctorat, Université des Sciences Humaines de Strasbourg U.F.R. des Sciences Historiques; CNRS-Centre de Sédimentologie et de Géochimie de la Surface: Strasbourg, France, 1988.

75. Buxeda i Garrigós, J.; Ontiveros, M.A.C. Identificación y significado de la calcita secundaria en cerámicas arqueológicas. Complutum 1995, 6, 293-309.

76. Prag, A.J.N.W.; Schweizer, F.; Williams, J.L.I.W.; Schubiger, P.A. Hellenistic glazed wares from Athens and southern Italy: Analytical techniques and applications. Archaeometry 1974, 16, 153-187. [CrossRef]

77. Wilson, D.E.; Day, P.M. Ceramic regionalism in Prepalatial Central Crete: The Mesara imports at EMI to EMIIA Knossos. Annu. Br. Sch. Athens 1994, 89, 1-87. [CrossRef]

78. Arvidson, R.S.; Ertan, I.E.; Amonette, J.E.; Luttge, A. Variation in calcite dissolution rates: A fundamental problem? Geochim. Cosmochim. Acta 2003, 67, 1623-1634. [CrossRef]

79. Chou, L.; Garrels, R.M.; Wollast, R. Comparative study of the kinetics and mechanisms of dissolution of carbonate minerals. Chem. Geol. 1989, 78, 269-282. [CrossRef]

80. Noiriel, C.; Steefel, C.I.; Yang, L.; Ajo-Franklin, J. Upscaling calcium carbonate precipitation rates from pore to continuum scale. Chem. Geol. 2012, 318-319, 60-74. [CrossRef]

81. Xu, J.; Fan, C.; Teng, H.H. Calcite dissolution kinetics in view of Gibbs free energy, dislocation density, and pCO $\mathrm{pC}_{2}$ Chem. Geol. 2012, 322-323, 11-18. [CrossRef]

82. Leslie, A.B.; Hughes, J.J. Binder microstructure in lime mortars: Implications for the interpretation of analysis results. Q. J. Eng. Geol. Hydrogeol. 2002, 35, 257-263. [CrossRef]

83. Lubelli, B.; Nijland, T.G.; van Hees, R.P.J. Self-healing of lime based mortars: Microscopy observations on case studies. Heron 2011, 56, 81-97.

84. Jackson, M.D.; Vola, G.; Všianský, D.; Oleson, J.P.; Scheetz, B.E.; Brandon, C.; Hohlfelder, R.L. Cement Microstructures and Durability in Ancient Roman Seawater Concretes. In Historic Mortars. RILEM Bookseries, Vol. 7; Válek, J., Hughes, J., Groot, C., Eds.; Springer: Dordrecht, The Netherlands, 2012; pp. 49-76. [CrossRef]

85. Glascock, M.D. Introduction: Geochemical Evidence for Long Distance Exchange. In Geochemical Evidence for Long Distance Exchange; Glascock, M., Ed.; Bergan and Garvey: London, UK, 2002; pp. 1-12.

86. Kilikoglou, V.; Grimanis, A.P.; Hein, A.; Malamidou, D.; Tsirtsoni, Z. Neutron activation patterning of archaeological materials at the National Center for Scientific Research 'Demokritos': The case of black-on-red Neolithic pottery from Macedonia, Greece. Archaeometry 2007, 49, 301-319. [CrossRef]

87. Day, P.M. The production and distribution of storage jars in Neopalatial Crete. In Problems in Greek Prehistory: Papers Presented at the Centenary Conference of the British School of Archaeology at Athens, Manchester, April 1986; French, E.B., Wardle, K.A., Eds.; Bristol Classical Press: Bristol, UK, 1988; pp. 499-508.

88. Aitchison, J. The Statistical Analysis of Compositional Data. In Monographs of Statistics and Applied Probability; Chapman and Hall: New York, NY, USA, 1986.

89. Buxeda i Garrigós, J.; Kilikoglou, V. Total Variation as a measure of variability in chemical datasets. In Patterns and Process. A Festschrift in Honor of Dr. Edward V. Sayre; van Zelst, L., Ed.; Smithsonian Center for Materials Research and Education: Washington, DC, USA, 2003; pp. 185-198.

90. Buxeda i Garrigós, J.; Kilikoglou, V.; Day, P.M. Chemical and Mineralogical Alteration of Ceramics from a Late Bronze Age Kiln at Kommos, Crete: The Effect on the Formation of a Reference Group. Archaeometry 2001, 43, 349-371. [CrossRef]

91. Mommsen, H.; Sjöberg, B.L. The Importance of the 'Best Relative Fit Factor' When Evaluating Elemental Concentration Data of Pottery, Demonstrated with Mycenaean Sherds from Sinda, Cyprus. Archaeometry 2007, 49, 357-369. [CrossRef]

92. Culbert, T.P. The Ceramic History of the Central Highlands of Chiapas, Mexico; Papers of the New World Archaeological Foundation No. 19; Brigham Young University: Provo, UT, USA, 1965.

93. Lee, T.A., Jr. El Asentamiento Humano Precolombino del Valle de Hueyzacatlan. In San Cristobal y Sus Alrededores; Gobierno del Estado de Chiapas: Tuxtla Gutierrez, Chiapas, Mexico, 1985; pp. 153-186. 
94. Paris, E.H.; López Bravo, R.; Lalo Jacinto, G. An Archaic Period Stemmed and Barbed Point from Tenam Puente, Chiapas, Mexico. Arqueol. Iberoam. 2019, 43, 62-66.

95. Prufer, K.M.; Alsgaard, A.V.; Robinson, M.; Meredith, C.R.; Culleton, B.J.; Dennehy, T.; Magee, S.; Huckell, B.B.; Stemp, W.J.; Awe, J.J.; et al. Linking late Paleoindian stone tool technologies and populations in North, Central and South America. PLoS ONE 2019, 14, e0219812. [CrossRef]

96. Paris, E.H. Cross-valley communities: Identity and interaction in Early Postclassic period highland Chiapas. J. Anthropol. Archaeol. 2014, 34, 78-99. [CrossRef]

97. Paris, E.H. Political Economy on the Postclassic Western Maya Frontier. Ph.D. Dissertation, Department of Anthropology, University at Albany, Albany, NY, USA, 2012.

98. Paris, E.H.; López Bravo, R. Gulf Coast influence at Moxviquil, Chiapas, Mexico. Camb. Archaeol. J. 2020, 30, 183-199. [CrossRef]

99. Paris, E.H.; López Bravo, R.; Serafin, S. A funerary cave at Moxviquil, Chiapas, Mexico. J. Field Archaeol. 2020, 45, 86-105. [CrossRef]

100. Weiant, C.W. Digging in Chiapas. Explor. J. 1954, 32, 30-36.

101. Mora, J.C.; Jaimes-Viera, M.C.; Garduño-Monroy, V.H.; Layer, P.W.; Pompa-Mera, V.; Godinez, M.L. Geology and geochemistry characteristics of the Chiapanecan Volcanic Arc (Central Area), Chiapas, Mexico. J. Volcanol. Geotherm. Res. 2007, 162, 43-72. [CrossRef]

102. León-Nájera, J.A.; Gómez-Álvarez, R.; Hernández-Daumás, S.; Álvarez-Solís, J.D.; Palma-López, D.J. Mineralización en suelos con incorporación de residuos orgánicos en los Altos de Chiapas, México. Univ. Y Cienc. 2006, 22, $163-164$.

103. Berlin, B.; Breedlove, D.E.; Raven, P.H. Principles of Tzeltal Plant Classification: An Introduction to the Botanical Ethnography of a Mayan Speaking People of Highland Chiapas; Academic Press: New York, NY, USA, 1974.

104. Breedlove, D.E. (Ed.) Flora of Chiapas; California Academy of Sciences: San Francisco, CA, USA, 1981.

105. Meanwell, J.L.; Paris, E.H.; López Bravo, R. Shifting domestic economies at Postclassic Period Moxviquil: Insights from ceramic petrography. In Proceedings of the Paper presented at the 82nd Annual SAA Meeting, Vancouver, BC, Canada, 29 March-2 April 2017.

106. Meanwell, J.L.; Paris, E.H.; López Bravo, R. Ceramic production and exchange networks in the Jovel Valley of Highland Chiapas. In Proceedings of the Paper Presented at the 118th Annual AAA/CASCA Meeting, Vancouver, BC, Canada, 20-24 November 2019.

107. Kennett, D.J.; Sackai, S.; Neff, H.; Gossett, R.; Larson, D.O. Compositional Characterization of Prehistoric Ceramics: A New Approach. J. Archaeol. Sci. 2002, 29, 443-455. [CrossRef]

108. Higgins, M.D.; Higgins, R. A Geological Companion to Greece and the Aegean; Cornell University Press: Ithaca, NY, USA, 1996.

109. Whitbread, I.K.; Mari, A. Provenance and Proximity: A technological analysis of Late and Final Neolithic ceramics from Euripides' Cave, Salamis, Greece. J. Archaeol. Sci. 2014, 41, 79-88. [CrossRef]

110. Kiriatzi, E.; Georgakopoulou, M.; Pendadeka, A. Section C. Pottery Production and Importation at Bronze Age Kolonna: The Ceramic Fabrics. In Pottery Production and Supply at Bronze Age Kolonna, Aegina; Gauss, W., Kiriatzi, E., Eds.; Verlag der Österreichen Akademie der Wissenschaften: Wien, Austria, 2011; pp. 69-145.

111. Gilstrap, W.D.; Day, P.M.; Kilikoglou, V. Pottery production at two neighbouring centres in the Late Bronze Age Saronic Gulf: Historical contingency and craft organisation. J. Archaeol. Sci. Rep. 2016, 7, 499-509. [CrossRef]

112. Hein, A.; Day, P.M.; Cau Ontiveros, M.A.; Kilikoglou, V. Red clays from Central and Eastern Crete: Geochemical and mineralogical properties in view of provenance studies on ancient ceramics. Appl. Clay Sci. 2004, 24, 245-255. [CrossRef]

113. Hein, A.; Day, P.M.; Quinn, P.S.; Kilikoglou, V. Geochemical diversity of Neogene clay deposits in Crete and its implications on Provenance studies of Minoan pottery. Archaeometry 2004, 46, 357-384. [CrossRef]

114. Hein, A.; Mommsen, H.; Zender, G. Pliocene clays from Aegina (Greece): Reference material for chemical provenance studies on Bronze Age pottery from the island. Geoarchaeology 2004, 19, 553-564. [CrossRef]

115. Ho, J.W.I.; Quinn, P.S. Intentional Clay-Mixing in the Production of Traditional and Ancient Ceramics and Its Identification in Thin Section. J. Archaeol. Sci. Rep. 2021, 37, 102945. [CrossRef]

116. Gilstrap, W.D. Ceramic production and exchange in the Late Mycenaean Saronic Gulf. Unpublished Doctoral Dissertation; University of Sheffield: Sheffield, UK, 2015.

117. Glascock, M.D. Characterization of Archaeological Ceramics at MURR by Neutron Activation Analysis and Multivariate Statistics. In Chemical Characterization of Ceramic Pastes in Archaeology; Neff, H., Ed.; Prehistory Press: Madison, WI, USA, $1992 ;$ pp. 11-26.

118. Paris, E.H.; Taladoire, E.; Lee Whiting, T. Return to Moxviquil. Anc. Mesoam. 2015, 26, 81-112. [CrossRef]

119. Fabbri, B.; Gualtieri, S.; Shoval, S. The presence of calcite in archaeological ceramics. J. Eur. Ceram. Soc. 2014, 34, 1899-1911. [CrossRef]

120. Bayazit, M.; Çağine, D.; Genç, E. Early Bronze Age Plain Simple Wares (Tripod Vessels) of Tilbeshar (Turkey): Archaeometric Characterization. BEU J. Sci. 2019, 8, 484-495.

121. Tenconi, M.; Maritan, L.; Mazzoli, C. Textural Changes in Speleothem Inclusions during Firing: A Useful Tool to Estimate Temperature in Speleothem-Bearing Pottery. Archaeometry 2016, 58, 39-53. [CrossRef]

122. Brady, J.E.; Scott, A.; Neff, H.; Glascock, M.D. Speleothem breakage, movement, removal, and caching: An aspect of ancient Maya cave modification. Geoarchaeology 1997, 12, 725-750. [CrossRef]

123. Moore, C.H. Concepts of Sequence Stratigraphy as Applied to Carbonate Depositional Systems. Dev. Sedimentol. 2001, 55, 19-36. [CrossRef] 
124. Cogswell, J.W.; Neff, H.; Glascock, M.D. Analysis of Shell-Tempered Pottery Replicates: Implications for Provenance Studies. Am. Antiq. 1998, 63, 63-72. [CrossRef]

125. Papavassiliou, C.; Chorianopoulou, P.; Tsaila-Monopolis, S.; Tsapralis, V.; Bornovas, J. Geological Map of Greece. 1:50,000. Athens Piraeus; IGME: Athens, Greece, 1982.

126. Burke, C.; Day, P.M.; Pullen, D.J. The contribution of petrography to understand the consumption of Early Helladic Ceramics from Nema, Mainland Greece. In Integrative Approaches in Ceramic Petrography; Ownby, M.F., Druc, I.C., Masucci, M.A., Eds.; University of Utah Press: Salt Lake City, UT, USA, 2016; pp. 104-115.

127. Day, P.M.; Rutter, J.B.; Quinn, P.S.; Kilikoglou, V. A World of Goods. Transport Jars and Commodity Exchange at the Late Bronze Age Harbour of Kommos, Crete. Hesperia 2011, 80, 511-558.

128. Neff, H. Quantitative Techniques for Analyzing Ceramic Compositional Data. In Ceramic Production and Circulation the Greater Southwest: Source Determination by INAA and Complimentary Mineralogical Investigations; Glowacki, D.M., Neff, H., Eds.; Cotsen Institute of Archaeology: Los Angeles, CA, USA, 2002; pp. 15-36.

129. Buxeda i Garrigós, J.; Cau Ontiveros, M.A. Possibilitats i Limitacions en l'estudi archaeométric de les produccions ceràmiques ebusitanes. Pyrenae 1998, 29, 97-115. 